Prepared for the U.S. Department of Energy

under Contract DE-AC05-76RL01830

\title{
Bringing Water into an Integrated Assessment Framework
}
R. César Izaurralde
Ronald D. Sands
Allison M. Thomson
Hugh M. Pitcher

November 2010

Pacific Northwest

NATIONAL LABORATORY

Proudly Operated by Battelle Since 1965 


\title{
DISCLAIMER
}

This report was prepared as an account of work sponsored by an agency of the United States Government. Neither the United States Government nor any agency thereof, nor Battelle Memorial Institute, nor any of their employees, makes any warranty, express or implied, or assumes any legal liability or responsibility for the accuracy, completeness, or usefulness of any information, apparatus, product, or process disclosed, or represents that its use would not infringe privately owned rights. Reference herein to any specific commercial product, process, or service by trade name, trademark, manufacturer, or otherwise does not necessarily constitute or imply its endorsement, recommendation, or favoring by the United States Government or any agency thereof, or Battelle Memorial Institute. The views and opinions of authors expressed herein do not necessarily state or reflect those of the United States Government or any agency thereof.

\author{
PACIFIC NORTHWEST NATIONAL LABORATORY \\ operated by \\ BATTELLE \\ for the \\ UNITED STATES DEPARTMENT OF ENERGY \\ under Contract DE-AC05-76RL01830
}

Printed in the United States of America
Available to DOE and DOE contractors from the Office of Scientific and Technical Information,
P.O. Box 62, Oak Ridge, TN 37831-0062;
ph: (865) 576-8401
fax: (865) 576-5728
email: reports@adonis.osti.gov

\author{
Available to the public from the National Technical Information Service, \\ U.S. Department of Commerce, 5285 Port Royal Rd., Springfield, VA 22161 \\ ph: (800) 553-6847 \\ fax: (703) 605-6900 \\ email: orders@ntis.fedworld.gov \\ online ordering: http://www.ntis.gov/ordering.htm
}

This document was printed on recycled paper.

$(9 / 2003)$ 


\section{Bringing Water into an Integrated Assessment Framework}

R César Izaurralde Ronald D. Sands

Allison M. Thomson Hugh M. Pitcher

November 2010

Prepared for

the U.S. Department of Energy

under Contract DE-AC05-76RL01830

Pacific Northwest National Laboratory

Richland, Washington 99352 



\section{Summary}

We developed a modeling capability to understand how water is allocated within a river basin and examined present and future water allocations among agriculture, energy production, other human requirements, and ecological needs.

Water is an essential natural resource needed for food and fiber production, household and industrial uses, energy production, transportation, tourism and recreation, and the functioning of natural ecosystems. Anthropogenic climate change and population growth are anticipated to impose unprecedented pressure on water resources during this century. Pacific Northwest National Laboratory (PNNL) researchers have pioneered the development of integrated assessment (IA) models for the analysis of energy and economic systems under conditions of climate change. This Laboratory Directed Research and Development (LDRD) effort led to the development of a modeling capability to evaluate current and future water allocations between human requirements and ecosystem services.

The Water Prototype Model (WPM) was built in STELLA ${ }^{\circledR}$, a computer modeling package with a powerful interface that enables users to construct dynamic models to simulate and integrate many processes (biological, hydrological, economics, sociological). A 150,404-km² basin in the United States (U.S.) Pacific Northwest region served as the platform for the development of the WPM. About $60 \%$ of the study basin is in the state of Washington with the rest in Oregon. The Columbia River runs through the basin for $874 \mathrm{~km}$, starting at the international border with Canada and ending (for the purpose of the simulation) at The Dalles dam. Water enters the basin through precipitation and from streamflows originating from the Columbia River at the international border with Canada, the Spokane River, and the Snake River. Water leaves the basin through evapotranspiration, consumptive uses (irrigation, livestock, domestic, commercial, mining, industrial, and off-stream power generation), and streamflow through The Dalles dam. Water also enters the Columbia River via runoff from land. The model runs on a monthly timescale to account for the impact of seasonal variations of climate, streamflows, and water uses. Data for the model prototype were obtained from national databases and ecosystem model results.

The WPM can be run from three sources: 1) directly from STELLA, 2) with the isee Player ${ }^{\circledR}$, or 3) the web version of WPM constructed with $\mathrm{NetSim}^{\circledR}$ software. When running any of these three versions, the user is presented a screen with a series of buttons, graphs, and a table. Two of the buttons provide the user with background and instructions on how to run the model. Currently, there are five types of scenarios that can be manipulated alone or in combination using the Sliding Input Devices: 1) interannual variability (e.g., El Niño), 2) climate change, 3) salmon policy, 4) future population, and 5) biodiesel production.

Overall, the WPM captured the effects of streamflow conditions on hydropower production. Under La Niña conditions, more hydropower is available during all months of the year, with a substantially higher availability during spring and summer. Under El Niño conditions, hydropower would be reduced, with a total decline of $15 \%$ from normal weather conditions over the year. A policy of flow augmentation to facilitate the spring migration of smolts to the ocean would also reduce hydropower supply. Modeled hydropower generation was $23 \%$ greater than the 81 TWh reported in the 1995 U.S. Geological Survey (USGS) database. The modeling capability presented here contains the essential features to conduct basinscale analyses of water allocation under current and future climates. Due to its underlying data structure 
and conceptual foundation, the WPM should be appropriate to conduct IA modeling at national and global scales. 


\section{Acknowledgments}

The authors wish to thank Gerry Stokes for his vision and support; Antoinette Brenkert and Jacob Oppenheim for data collection, processing, and modeling support; and Charity Plata and Kim Swieringa for technical editing. The work was funded by PNNL under the Laboratory Directed Research and Development program. 


\section{Acronyms and Abbreviations}

$\begin{array}{ll}\text { aMW } & \text { average Megawatts } \\ \text { BMRC } & \text { Australian Bureau of Meteorological Research Centre } \\ \text { BPA } & \text { Bonneville Power Administration } \\ \text { ENSO } & \text { El Niño Southern Oscillation } \\ \text { EPIC } & \text { Environmental Policy Integrated Climate } \\ \text { GCM } & \text { Global Climate Model(s) } \\ \text { GMT } & \text { global mean temperature } \\ \text { ha } & \text { hectares } \\ \text { HUA } & \text { hydrologic unit area(s) } \\ \text { HUC } & \text { Hydrological Unit Code } \\ \text { HUMUS } & \text { Hydrologic Unit Model of the United States } \\ \text { IA } & \text { Integrated Assessment } \\ \text { LDRD } & \text { Laboratory Directed Research and Development } \\ \text { NRC } & \text { National Research Council } \\ \text { PNNL } & \text { Pacific Northwest National Laboratory } \\ \text { UIUC } & \text { University of Illinois, Urbana Champaign } \\ \text { U.S. } & \text { United States } \\ \text { USDA } & \text { United States Department of Agriculture } \\ \text { USGS } & \text { United States Geological Survey } \\ \text { WPM } & \text { Water Prototype Model } \\ \text { WRIA } & \text { Water Resource Inventory Areas }\end{array}$




\section{Contents}

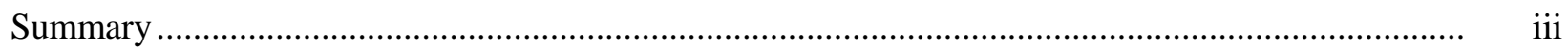

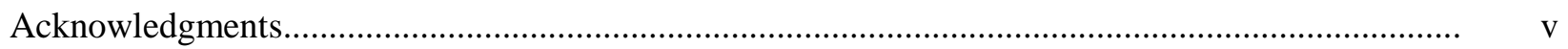

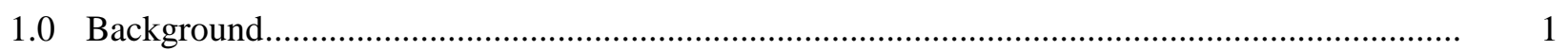

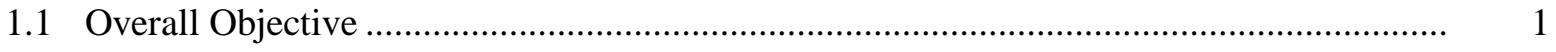

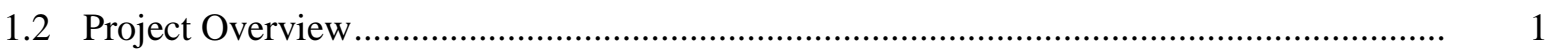

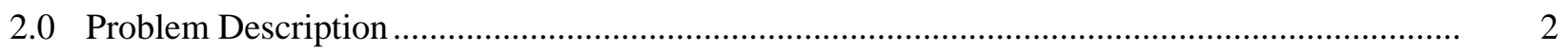

2.1 Basin Selection ................................................................................................. 2

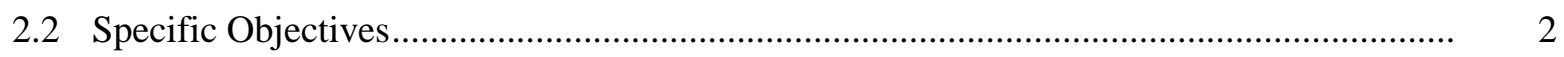

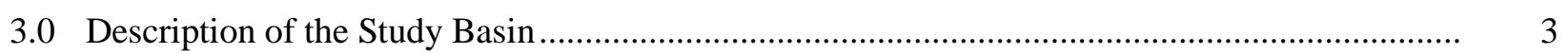

3.1 Physiographic Features of the Study Basin .................................................................. 3

3.2 Population and Economic Activity ........................................................................... 5

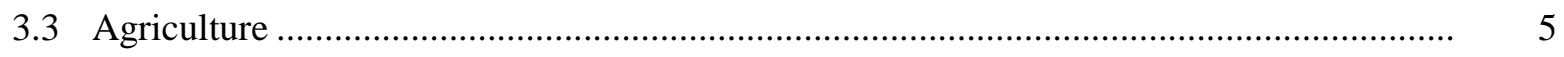

3.4 Water Resources................................................................................................ 7

3.5 A Simple Water Balance of the Study Basin ................................................................. 8

3.6 Seasonal Variations of Streamflow and Spatial Distribution of Water Use ........................ 8

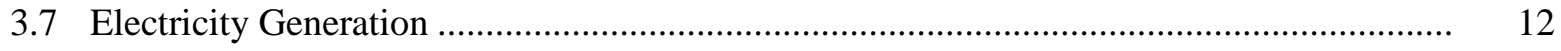

3.8 Major Issues — Water, Energy, and Salmon ............................................................. 14

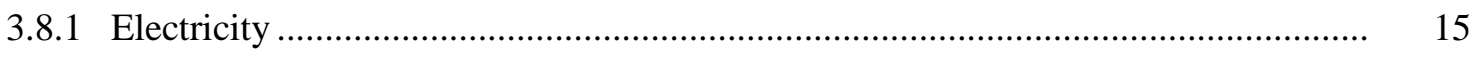

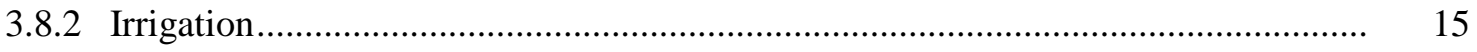

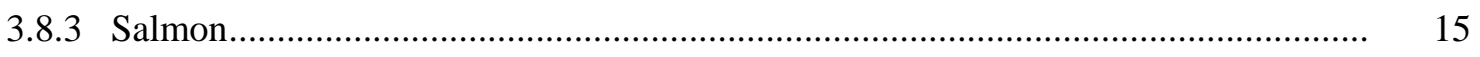

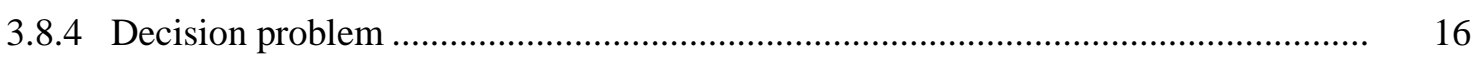

3.9 The Future - Climate Change, Legal Issues, and Demographic Changes ......................... 16

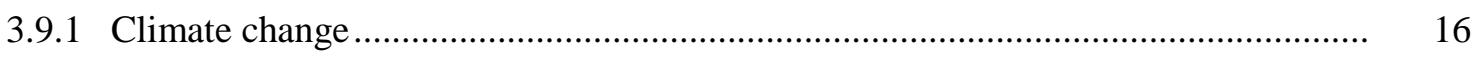

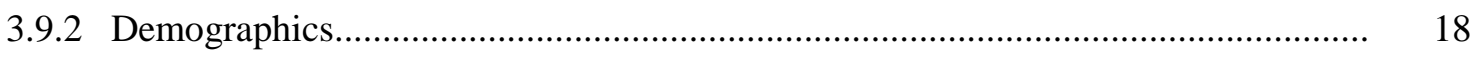

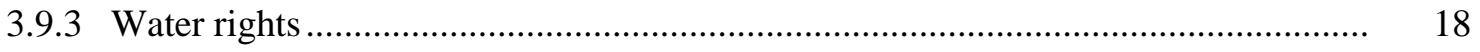

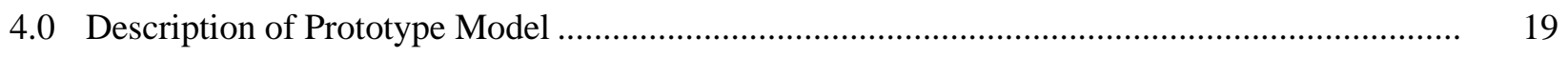

4.1 Description of the Water Prototype Model ….............................................................. 19

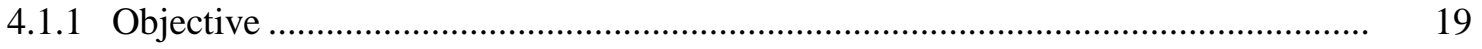

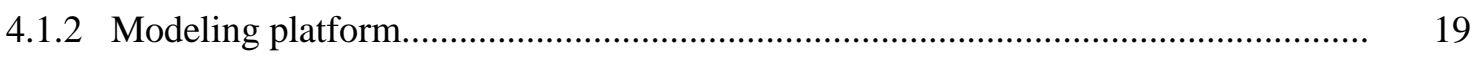

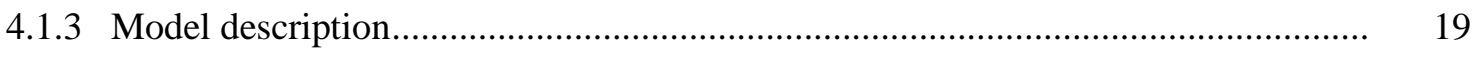

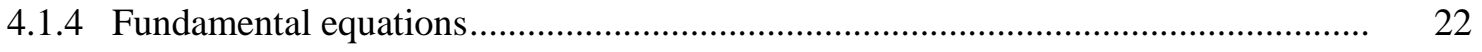

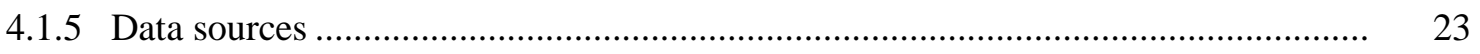

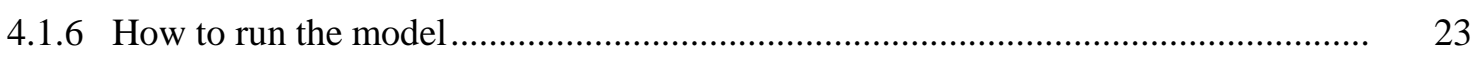

4.1.7 Examples and discussion of selected model outputs ............................................... 24

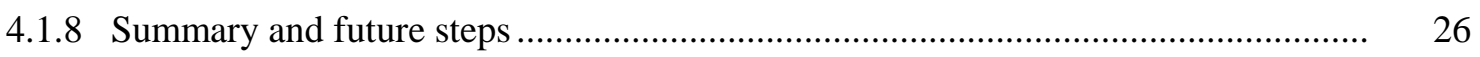

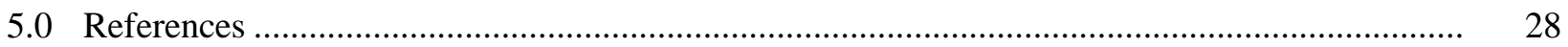




\section{Figures}

Figure 1. Study Basin in Eastern Washington and Northern Oregon ...............................................

Figure 2. Physiographic Features of the Pacific Northwest ...............................................................

Figure 3. Geographic Distribution of Annual Precipitation in the Study Region and Surrounding Areas.....

Figure 4. Water Balance Calculations and Additional Consumptive-use Allocations for Watersheds of the Columbia Basin.

Figure 5. Surface Responses of Crop Yield $\left(\mathrm{Mg} \mathrm{ha}^{-1}\right)$ as Affected by Increases in Global Mean Temperatures and Atmospheric $\mathrm{CO}_{2}$ Concentrations in the Columbia Basin .

Figure 6. Surface Responses of Grape and Apple Yields $\left(\mathrm{Mg} \mathrm{ha}^{-1}\right)$ as Affected by Increases in Global Mean Temperatures and Atmospheric $\mathrm{CO}_{2}$ Concentrations in the Columbia Basin

Figure 7. Model Diagram Showing the Larger Compartments and the Stocks and Flow Occurring Throughout.

Figure 8. Screenshot of the Water Prototype Model Interface..........................................................

Figure 9. Predicted and Observed Streamflows (m3) at The Dalles as Affected by ENSO Scenarios

Figure 10. Monthly Hydropower (kWh) as Affected by ENSO Scenarios

Figure 11. Simplified Version of the Bonneville Power Administration Model to Describe Smolts Migration to the Ocean 


\section{Tables}

Table 1. 1997 and 2002 USDA Census Data of Irrigated Crops in the Study Basin.......................... 6

Table 2. Area Harvested and Production of Various Dryland Agricultural Commodities .................. 6

Table 3. Area Harvested and Production of Various Irrigated Agricultural Commodities.................. 7

Table 4. Area Harvested and Production of Irrigated and Non-irrigated Agricultural Commodities... 7

Table 5. Simple Annual Water Balance of the Study Basin Based on Observed Water Flows, Observed Precipitation, Simulated Evapotranspiration, and Estimated Water Withdrawals ....... 9

Table 6. Monthly and Annual Streamflows of the Columbia River at the John Day Dam and Monthly and Annual Water Withdrawals from the Columbia River

Table 7. Locations and Characteristics of Dams Located on the Columbia River Within the Study

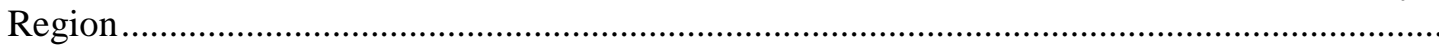





\subsection{Background}

\subsection{Overall Objective}

The overall objective of this project is to develop a quantitative understanding of how water is allocated within a watershed among its many uses, such as: agriculture, energy production, transportation, recreational activities, ecosystems, industrial, and municipal.

\subsection{Project Overview}

Water is an essential natural resource needed for food and fiber production, household and industrial uses, energy production, transportation, tourism and recreation, and the functioning of natural ecosystems. In most parts of the world, water resources are already subject to great stress. During this century, climate change, population growth, increased demand for animal protein due to rising incomes, and the potential for large-scale biomass production for climate change mitigation are anticipated to impose unprecedented pressure on already stressed water resources. Our integrated assessment (IA) modeling capability to analyze the impacts of climate change on water resources has been limited to the area of water availability and demand in agriculture in the conterminous United States (U.S.) (Izaurralde et al. 2003; Rosenberg et al. 2003; and Thomson et al. 2005a, b, and c). These modeling studies allowed for the calculation of the potential changes in irrigation under a variety of climate change scenarios, while taking into consideration many biophysical processes, such as: precipitation, air temperature, evapotranspiration, runoff, transpiration suppression, and the $\mathrm{CO}_{2}$ fertilization effect. There is a need, however, to consider the complexity of other water issues such as water use and re-use (e.g., energy, ecosystems, agriculture, municipal, and industrial), flow modifications (reservoirs), and water quality. Availability of these data would be essential for integrating water into an IA modeling framework. Our specific objective is to expand our capability to represent the multiple functions of water in energy, economic, and environmental systems within an IA framework. 


\subsection{Problem Description}

\subsection{Basin Selection}

Initially, we proposed to select a river basin in the southeastern U.S. and conduct a retrospective analysis of the development of the structure and conflicts of water resources. The criteria for basin selection included current water usage and associated conflicts, potential for continued increase in human demands for a variety of uses, and prospects for developing an understanding of institutional relationships governing water. In January 2006, H.M. Pitcher, A.M. Thomson, A.L. Brenkert, R.D. Sands, and R.C. Izaurralde from the Joint Global Change Research Institute held a teleconference with colleagues R. Skaggs, M.J. Scott, R. Leung, and L.W. Vail from Pacific Northwest National Laboratory (PNNL) to consider the possibility of selecting a basin in the Pacific Northwest. The rationale for the proposed selection was based on 1) a previous water study in the Yakima Basin led by M.J. Scott, 2) regional climate simulations by R. Leung, 3) regional hydrological modeling studies by L.W. Vail, and 4) PNNL activities in the energy-water nexus as reported by R. Skaggs. Based on these considerations, we decided to select a basin in the Pacific Northwest in order to develop a model prototype to analyze the role of water within an IA framework.

\subsection{Specific Objectives}

The specific objective of the Laboratory Directed Research and Development (LDRD) project was to build a model prototype that describes the uses of water, as well as their interactions with energy systems and environmental conditions. To develop the model, we started with a description of the study basin in terms of its biophysical, environmental, and economic characteristics. 


\subsection{Description of the Study Basin}

The basin selected is part of the Columbia Basin, a large basin covering parts of Canada and the U.S. with two major tributaries - the Columbia and Snake rivers. The study basin was selected to cover parts of the states of Washington and Oregon (Figure 1). It excludes part of the Columbia Basin in Canada and the area draining into the Snake River.

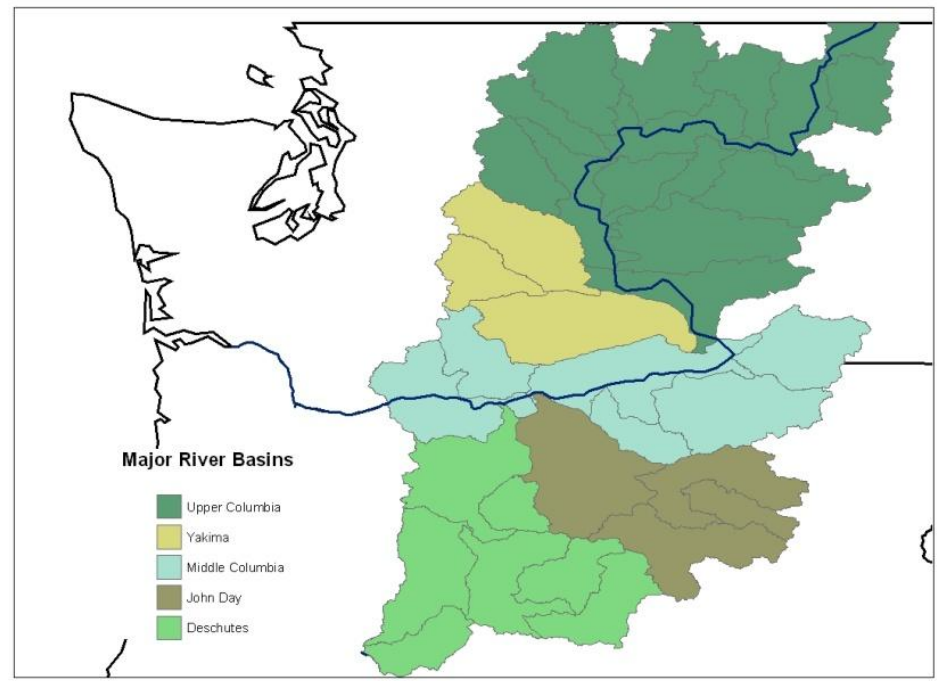

Figure 1. Study Basin in Eastern Washington and Northern Oregon. The basin comprises five, 4digit United States Geological Survey (USGS) subbasins that drain into the Columbia River.

\subsection{Physiographic Features of the Study Basin}

The basin selected contains five, 4-digit and 39, 8-digit USGS basins and extends over $150,404 \mathrm{~km}^{2}$ of territory-about $60 \%$ resides in Washington with the rest in Oregon.

In terms of its physiography, the region was developed over basalt materials deposited millions of years ago. ${ }^{1}$ Tectonic movements led to the formation of ridges and valleys, while the eroding force of rivers contributed to wear down of the ridges and redeposit of eroded materials in valleys, leading to the current physiographic configuration of the region. The topography of the study basin varies from sandy plains and plateaus to mountain slopes and rocky ridgelines (Figure 2). Elevations range from $150 \mathrm{~m}$ to more than $1,000 \mathrm{~m}$ above sea level.

The climate of the basin is hot and dry during the summer with maximum temperatures often exceeding $40^{\circ} \mathrm{C}$. Winters bring wet and cold weather with strong winds and blowing snow. Minimum temperatures in winter often dip to $-15^{\circ} \mathrm{C}$. The lower Columbia Basin rests deep within the rain shadow of the Cascade Mountains, so it receives only between 100-230 mm of annual precipitation (Figure 3), of which about half occurs as snow. Toward the foothills, precipitation ranges between $400-600 \mathrm{~mm}$.

${ }^{1}$ http://www.pnl.gov/pals/handbook/part1_1.pdf\#search=\%22columbia\%20basin\%20physiography\% 22. 


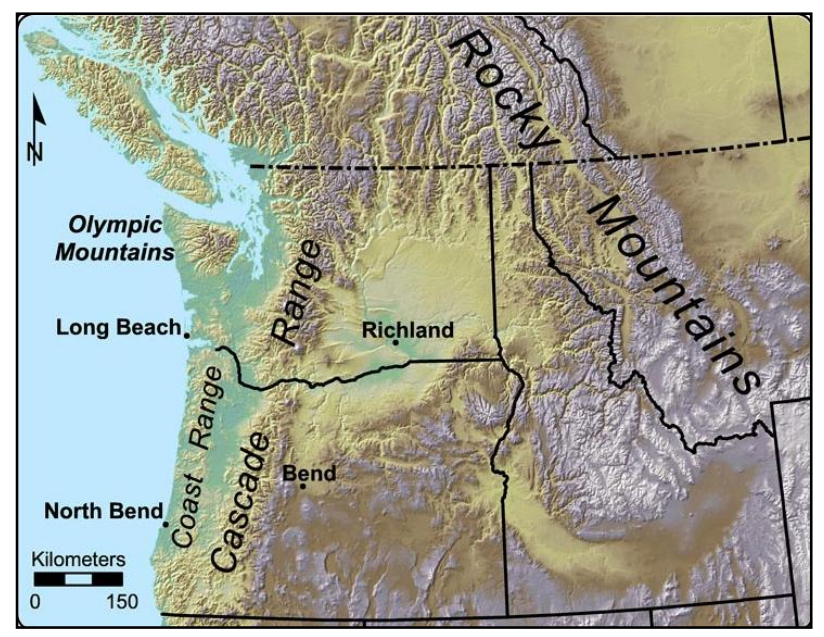

Figure 2. Physiographic Features of the Pacific Northwest. The study basin corresponds approximately with the Walla Walla plateau.

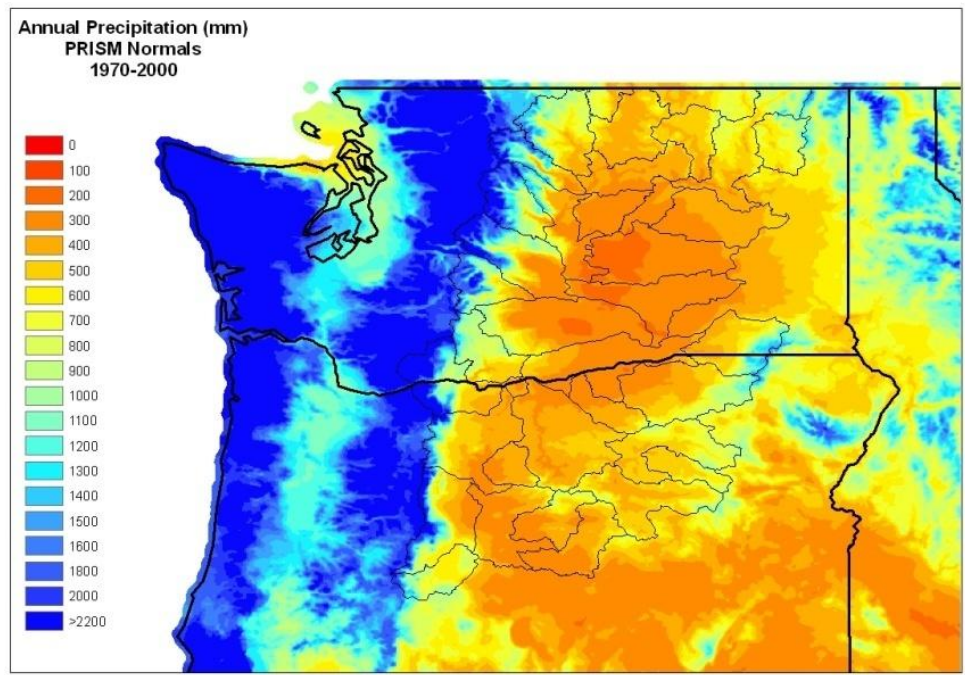

Figure 3. Geographic Distribution of Annual Precipitation in the Study Region (polygons delineated in black) and Surrounding Areas. Notice the rain shadow effect east of the Cascade Mountains (blue and yellow-brown colors along the divortium aquarum of the Cascade Mountains).

Natural vegetation is typical of desert areas, and it is described broadly as shrub-steppe ${ }^{2}$. Dominant shrubs include big sagebrush (Artemisia tridentata Nutt.), spiny hop sage (Grayia spinosa (Hook.) Moq.), antelope bitterbrush (Purshia tridentata (Pursh) DC.), black greasewood (Sarcobatus vermiculatus (Hook.) Torr.), and threetip sagebrush (Artemisia tripartita Rydb.). Large bunchgrasses and flowering forbs make up the rest of the shrub-steppe plant community. Along the streams, the natural vegetation consists of reeds, rushes, and cattails, as well as

${ }^{2}$ http://extension.usu.edu/rangeplants/index.htm. 
deciduous trees and shrubs. The fauna of the region includes about 40 species of mammals, 246 species of birds (some migratory), five species of amphibians, and 10 species of reptiles. The Columbia River and its tributaries within the study basin serve as habitat for numerous species of fish (some introduced, others migratory), such as: bluegill sunfish (Lepomis macrochirus), carp (Cyprinus carpio), channel catfish (Ictalurus punctatus), Chinook salmon (Oncorhynchus tshawytscha), largemouth bass (Micropterus salmonoides), mosquitofish (Gambusia affinis), smallmouth bass (Micropterus dolomieui), and rainbow trout (Salmo gairdneri). ${ }^{3}$

\subsection{Population and Economic Activity}

Humans have inhabited the Pacific Northwest region for more than 10,000 years. About 3,500 years ago, the inhabitants of the area made a dietary and lifestyle transition from nomadic communities hunting large animals to sedentary communities relying on salmon fishing for their sustenance and culture (NRC 2004). Large tribal fisheries existed towards the end of the 18th century at the Willamette, Cascades, and Celillo Falls in the Columbia River. ${ }^{4}$ Soon after the completion of the historic Lewis and Clark expedition, European settlement began early in the 19th century. Since then, the region has undergone significant economic and environmental transformations with activities such as mining, livestock, dryland agriculture, and timber harvesting. The construction of numerous dams along the Columbia River for energy production and irrigated agriculture during the 20th century brought significant economic progress to the region, but had the adverse effect of altering the normal course of the salmon runs.

Total population in the study basin reached 1 million by 1995, with approximately three quarters of the population living in Washington and the rest in Oregon. ${ }^{5}$ The largest urban development is the Tri-Cities area in the state of Washington, a conglomerate of three cities, Richland, Kennewick, and Pasco, with an approximate population of 125,000 in 2000. ${ }^{6}$ The population of Benton and Franklin counties, where these urban centers are located, totaled about 170,000 people in $1995 .^{7}$

\subsection{Agriculture}

Data from the 2000 census reveal that of the total 15,040,400 hectares (ha) representing the study basin, 1,429,099 ha are used to plant crops, and, of these, 91,864 ha are under irrigation. However, the U.S. Department of Agriculture (USDA) reported that 111,598 ha bearing orchards in 1997 were 99\% irrigated (Table 1). Data from 2002 show an increase in area for almost all crops. The USGS reported 895,351 ha of irrigated land in the study basin (1995 USGS Hydrological Unit Code [HUC] data), which falls well within the range reported by the USDA for total hectares planted with crops.

In 2000, the USDA did not report if certain commodities (corn, peas, hay, oats, potatoes, and sugarbeets) within the study basin were irrigated (Table 2).

\footnotetext{
${ }^{3}$ http://www.pnl.gov/ecology/Rivers.html.

${ }^{4} \mathrm{http} / / /$ oregonstate.edu/instruct/anth481/sal/crintro1.htm.

${ }^{5} \mathrm{http}: / /$ water.usgs.gov/watuse/spread95.html.

${ }^{6} \mathrm{http}: / /$ en.wikipedia.org/wiki/Tri-Cities,_Washington.

${ }^{7}$ http://www.workforceexplorer.com/admin/uploadedPublications/385_tricity.pdf.
} 
Table 1. 1997 and 2002 USDA Census Data of Irrigated Crops in the Study Basin

\begin{tabular}{llll}
\hline Crop & No. of Farms (1997) & Area (ha) 1997 & 2002 \\
\hline Apples (1997) & 3,265 & 59,108 & 71,153 \\
Apricots & 256 & 355 & 493 \\
Sweet cherries & 2,117 & 13,230 & 18,310 \\
Cherries (tart) & 58 & 47 & 437 \\
Grapes & 928 & 21,698 & 25,332 \\
Hazelnuts (Filberts) & 14 & 2 & 7 \\
Kiwi fruit & 4 & 0 & 0 \\
Nectarines & 162 & 409 & 601 \\
Other fruits and nuts & 35 & 21 & 40 \\
Peaches, & 321 & 930 & 1,325 \\
Pears & 1,753 & 15,432 & 17,371 \\
Plums and prunes & 160 & 354 & 448 \\
Walnuts & 51 & 13 & 32 \\
Total & 9,124 & 111,598 & 135,547 \\
\hline
\end{tabular}

There are other commodities reported as 100\% irrigated (all beans) (Table 3), and certain commodities for which irrigation reporting seemed to be county-dependent (e.g., barley and wheat).

For barley, irrigation increases yield by $74 \%$. For "all wheat," the increase is $80 \%$. For spring wheat, the yield is $170 \%$, and winter wheat yield increases $68 \%$ (Table 4). As expected, the yield responses to irrigation vary by county with Yakima consistently showing the greatest increase in yield (data not shown).

Table 2. Area Harvested and Production of Various Dryland Agricultural Commodities

\begin{tabular}{lll}
\hline Commodity & Area harvested (ha) & Production $(\mathrm{Mg})$ \\
\hline Corn For Grain Total & 34,034 & 379,621 \\
Corn For Silage Total & 8,296 & 592,500 \\
Green Peas For Processing Total & 14,038 & 83,600 \\
Hay Alfalfa (Dry) Total & 210,841 & $2,704,300$ \\
Hay All (Dry) Total & 311,203 & $3,443,000$ \\
Hay Other (Dry) Total & 100,362 & 738,700 \\
Oats Total & 2,711 & 7,750 \\
Potatoes All Total & 78,873 & $5,478,348$ \\
Sugarbeets Total & 11,331 & 822,900 \\
\hline
\end{tabular}


Table 3. Area Harvested and Production of Various Irrigated Agricultural Commodities

\begin{tabular}{llll}
\hline Commodity & Practice & $\begin{array}{l}\text { Area harvested } \\
\text { (ha) }\end{array}$ & $\begin{array}{l}\text { Production } \\
(\mathrm{Mg})\end{array}$ \\
\hline Beans Dry Edible All & Irrigated equals Total & 8,377 & 21,772 \\
Pink Beans & Irrigated equals Total & 607 & 2,087 \\
Pinto Beans & Irrigated equals Total & 4,047 & 10,478 \\
Small Red Beans & Irrigated equals Total & 405 & 1,089 \\
Small White Beans & Irrigated equals Total & 283 & 680 \\
\hline
\end{tabular}

Table 4. Area Harvested and Production of Irrigated and Non-irrigated Agricultural Commodities

\begin{tabular}{llll}
\hline Commodity & Practice & Area harvested (ha) & Production $(\mathrm{Mg})$ \\
\hline Barley & Irrigated Total & 2,995 & 13,821 \\
& Non Irrigated Total & 44,313 & 117,761 \\
\multirow{3}{*}{ Wheat (all) } & Total For Crop & 117,197 & 381,890 \\
& Irrigated Total & 106,270 & 703,514 \\
& Non Irrigated Total & 570,526 & $2,097,436$ \\
Wheat Other Spring & Total For Crop & $1,006,453$ & $4,089,740$ \\
& Irrigated Total & 38,081 & 250,988 \\
\multirow{3}{*}{ Wheat Winter (all) } & Non Irrigated Total & 102,628 & 250,610 \\
& Total For Crop & 227,393 & 741,148 \\
& Irrigated Total & 68,190 & 452,526 \\
& Non Irrigated Total & 472,309 & $1,864,614$ \\
& Total For Crop & 779,060 & $3,348,592$ \\
\hline
\end{tabular}

\subsection{Water Resources}

The Columbia River Basin covers an area of $673,397 \mathrm{~km}^{2}$ from its headwaters in British Columbia, Canada, to its mouth at Astoria, Oregon. We selected a 150,404 $\mathrm{km}^{2}$ region of the basin in eastern Oregon and Washington, composing the mainstem of the Columbia River and the area beginning with the reservoir upstream from the Grand Coulee Dam and ending at the Bonneville Dam (Figure 1). The average annual flow for the Columbia River at The Dalles, Oregon, is approximately $5,448 \mathrm{~m}^{3} \mathrm{~s}^{-1}$. The river's annual discharge rate fluctuates with precipitation and ranges from $3,171 \mathrm{~m}^{3} \mathrm{~s}^{-1}$ in a low (drought) water year (e.g., 2001) to $7,589 \mathrm{~m}^{3}$ $\mathrm{s}^{-1}$ in a high water year (e.g., 1997). Land cover changes, particularly the reduced maturity of forested areas, have altered the hydrology of the river system over the past century, increasing runoff and reducing evapotranspiration (Matheussen et al. 2000).

The study area has a winter precipitation pattern with two thirds falling between October and March. Total annual precipitation ranges from 200-600 mm and is strongly dependent on elevation change (see Figure 2). Historically, multi-year droughts are a typical fluctuation in the Columbia Basin, with droughts in the 1840s and 1930s ranked as most severe (Gedalof et al. 
2004). The period of 1950-1987 was unique because of the lack of multi-year drought events. Further, streamflow in the Columbia River has been linked to large-scale climate fluctuations, such as the interannual El Niño Southern Oscillation (ENSO) and the Pacific Decadal Oscillation. Under the warm phase of both events, the region is warmer and drier with lower winter snowfall and streamflow. During the cold phase, the region is cooler and wetter. Because the area is dry and dominated by winter precipitation, the primary supply of water is snowpack in the mountain ranges to the east and west of the central Columbia Basin. This natural reservoir holds the winter precipitation and releases it throughout spring and into summer. The timing of this snowmelt is critical to both human activities and salmon survival. Artificial reservoirs have been created behind dams along almost the entire mainstem of the Columbia River.

Since construction of dams for flood control and power production began in the 1930s, the flow regime of the river has changed. Records kept since 1878 show that flows were much higher in the spring and lower in winter, and water velocity was much greater before dam construction. In 1917, the state of Washington adopted a water code to help manage water allocations. Since then, it has allocated hundreds of surface and ground water rights on the Columbia River. Water users have the right to take approximately $1,209 \mathrm{~m}^{3} \mathrm{~s}^{-1}$ in instantaneous withdrawals from April through October, the growing season for most crops in the basin. The total annual withdrawal from the mainstem Columbia River during the growing season is about $580,137 \mathrm{~m}^{3}$ of water. The Bureau of Reclamation is the single largest water user on the river and is allocated about two thirds of the water.

\subsection{A Simple Water Balance of the Study Basin}

Based on observed and simulated data from various sources, a simple annual water balance equation was constructed (Table 5). Overall, there is a good agreement between observed $\left(D_{\text {observed }}=17.2 \times 10^{10} \mathrm{~m}^{3} \mathrm{y}^{-1}\right)$ and estimated $\left(D_{\text {estimated }}=17.1 \times 10^{10} \mathrm{~m}^{3} \mathrm{y}^{-1}\right)$ streamflows of the Columbia River at The Dalles, Oregon. Methodologically, this is quite important in developing a mass balance system to calculate water transactions based on altered streamflows, precipitation, evapotranspiration, water withdrawals, and in-stream water uses.

\subsection{Seasonal Variations of Streamflow and Spatial Distribution of Water Use}

Monthly flows and the possible seasonal shifts from potential climate change are more important than yearly totals given the multi-use aspects of the water from the Columbia River, i.e., electricity demand from hydropower, irrigation needs during dry periods, and sufficient flows during the migration of salmon smolts to the ocean. 
Table 5. Simple Annual Water Balance of the Study Basin Based on Observed Water Flows, Observed Precipitation, Simulated Evapotranspiration, and Estimated

Water Withdrawals

\begin{tabular}{|c|c|c|c|}
\hline $\begin{array}{l}\text { Water balance } \\
\text { term }^{\dagger}\end{array}$ & Sources & Data type & $\begin{array}{l}\text { Annual flow } \\
\left(10^{10} \mathrm{~m}^{3} \mathrm{y}^{-1}\right)\end{array}$ \\
\hline I & $\begin{array}{l}\text { Streamflow of Columbia River at the } \\
\text { International Canada-U.S. Border }\end{array}$ & Observed & 8.9 \\
\hline$S$ & $\begin{array}{l}\text { Streamflow of Snake River } \\
\text { (near Richland, Washington) }\end{array}$ & Observed & 4.8 \\
\hline $\mathrm{P}$ & Precipitation (from the HUMUS model) & Observed & 7.5 \\
\hline $\mathrm{E}$ & $\begin{array}{c}\text { Evapotranspiration } \\
\text { (from the HUMUS model) }\end{array}$ & Simulated & 3.1 \\
\hline $\mathrm{W}$ & Water withdrawals (from USGS data) & Estimated & 1.0 \\
\hline D & $\begin{array}{c}\text { Streamflow of Columbia River at The } \\
\text { Dalles, Oregon }\end{array}$ & Observed & 17.2 \\
\hline
\end{tabular}

'Explanation of water balance terms: I=streamflow at international border, $\mathrm{S}=$ streamflow of Snake River, $\mathrm{P}=$ precipitation, $\mathrm{E}=$ evapotranspiration, $\mathrm{W}=$ water withdrawals, and $\mathrm{D}=$ streamflow at The Dalles. The water balance equation is $\mathrm{D}=\mathrm{I}+\mathrm{S}+\mathrm{P}-\mathrm{E}-\mathrm{W}$. $\mathrm{D}_{\text {estimated }}=17.1 \times 10^{10} \mathrm{~m}^{3} \mathrm{y}^{-1} ; \mathrm{D}_{\text {observed }}=17.2 \times 10^{10} \mathrm{~m}^{3} \mathrm{y}^{-1}$.

Table 6 shows monthly streamflow data of the Columbia River at the John Day Dam (i.e., mean, high, and low flows) in comparison to monthly water withdrawals (NRC 2004). The NRC data also give the monthly summed upstream withdrawals at the John Day Dam. In average and above-average flow years, percentages indicate most water is withdrawn in August. In dry years, the most water is withdrawn in the spring through July. It is clear from the John Day information that much of the natural variability of the streamflow is retained, but a maximum of $16.6 \%$ of that flow is withdrawn in July in a dry year in addition to reducing the streamflow by nearly $10 \%$ each of the three months preceding July for agricultural irrigation.

The USGS provides two data sets regarding water supply and demand. One set is based on county delineations, while the other is based on 4-digit watersheds, or hydrologic unit area 4 (HUA4). Counties and watersheds do not necessarily overlap. However, for the study basin chosen in this study, the major aspects of the water balance (i.e., irrigation) do not differ significantly.

Following up on the USGS approach to an irrigation water balance, where return flow is calculated as total withdrawal for irrigation minus the sum of consumptive use by irrigation and conveyance losses (http://water.usgs.gov/watuse/tables/irtab.huc.html), we find 10,063 million $\mathrm{m}^{3}$ withdrawn for irrigation, per the 1995 USGS HUA data, and 10,319 million $\mathrm{m}^{3}$ according to the 1995 USGS county data. Those totals include 4,442, million $\mathrm{m}^{3}$ versus 4,535 million $\mathrm{m}^{3}$ for consumptive irrigation use, and 1,776 million $\mathrm{m}^{3}$ versus 1,832 million $\mathrm{m}^{3}$ for conveyance losses, resulting in 3,845 million $\mathrm{m}^{3}$ versus 3,952 million $\mathrm{m}^{3}$ left for return flows. 
Table 6. Monthly and Annual Streamflows of the Columbia River at the John Day Dam and Monthly and Annual Water Withdrawals from the Columbia River (adapted from Managing the Columbia River: Instream Flows, Water Withdrawals, and Salmon Survival, Table 3.1 after unit conversion (NRC 2004))

\begin{tabular}{|cccccccc|}
\hline & $\begin{array}{c}\text { Mean flow } \\
\mathrm{m}^{3} \mathrm{mo}^{-1}\end{array}$ & $\begin{array}{c}\text { Maximum } \\
\text { flow } \\
\mathrm{m}^{3} \mathrm{mo}^{-1}\end{array}$ & $\begin{array}{c}\text { Minimum } \\
\text { flow } \\
\mathrm{m}^{3} \mathrm{mo}^{-1}\end{array}$ & $\begin{array}{c}\text { Withdrawals } \\
\mathrm{m}^{3} \mathrm{mo}^{-1}\end{array}$ & $\begin{array}{c}\text { \% of } \\
\text { flow }\end{array}$ & $\begin{array}{c}\text { \% of } \\
\text { Max } \\
\text { flow }\end{array}$ & $\begin{array}{c}\text { \% of Min } \\
\text { flow }\end{array}$ \\
\hline Jan & 11,952 & 19,982 & 6,698 & 13 & 0.10 & 0.10 & 0.20 \\
Feb & 11,718 & 22,449 & 7,080 & 12 & 0.10 & 0.10 & 0.20 \\
April & 13,692 & 25,163 & 7,648 & 136 & 1.00 & 0.50 & 1.80 \\
May & 21,216 & 36,264 & 10,004 & 944 & 4.40 & 2.60 & 9.40 \\
June & 23,436 & 42,802 & 8,782 & 977 & 4.20 & 2.30 & 11.10 \\
\hline July & 15,419 & 26,397 & 6,303 & 1,048 & 6.80 & 4.00 & 16.60 \\
Aug & 10,349 & 16,529 & 6,685 & 978 & 9.50 & 5.90 & 14.60 \\
Sept & 7,919 & 11,422 & 5,279 & 614 & 7.80 & 5.40 & 11.60 \\
\hline Oct & 8,523 & 12,828 & 6,698 & 338 & 4.00 & 2.60 & 5.00 \\
\hline Nov & 9,054 & 11,447 & 6,377 & 15 & 0.20 & 0.10 & 0.20 \\
\hline Dec & 10,941 & 18,626 & 6,426 & 15 & 0.10 & 0.10 & 0.20 \\
\hline Annual & $\begin{array}{c}159,144 \\
\mathrm{~m}^{3} \mathrm{yr}^{-1}\end{array}$ & $\begin{array}{c}268,332 \\
\mathrm{~m}^{3} \mathrm{yr}^{-1}\end{array}$ & $\begin{array}{c}85,283 \\
\mathrm{~m}^{3} \mathrm{yr}^{-1}\end{array}$ & $\begin{array}{c}5,827 \\
\mathrm{~m}^{3} \mathrm{yr}^{-1}\end{array}$ & $3.70 \%$ & $2.20 \%$ & $6.80 \%$ \\
\hline
\end{tabular}

From upstream to downstream, those same water balance calculations are shown as pie charts for each 8-digit watershed in the left panel of Figure 4. The right panel shows the additional consumptive-use allocations (commercial, domestic, industrial, mining, livestock, and thermoelectric) for each of those watersheds.

Of note, the John Day and Deschutes watersheds in Oregon show close to zero industrial water use, and the reported water use in the John Day watershed is mainly for livestock. Only electricity generation outside of hydropower occurs in the Middle Columbia, and domestic water use tends to be more than double commercial water use in these watersheds. 

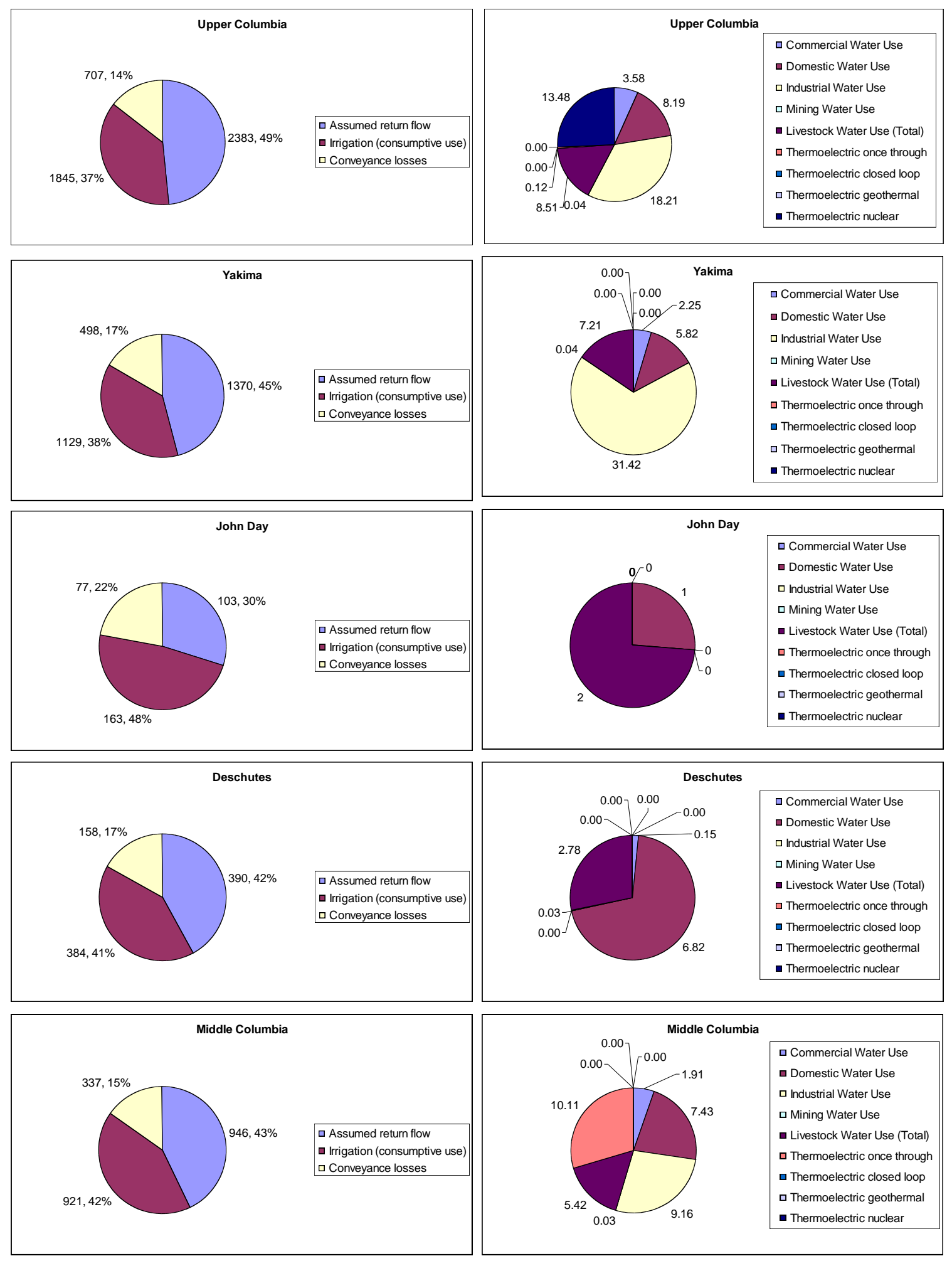

Figure 4. Water Balance Calculations (left panel) and Additional Consumptive-use Allocations (commercial, domestic, industrial, mining, livestock, and thermoelectric) for Watersheds of the Columbia Basin 


\subsection{Electricity Generation}

From an economic modeling perspective, the Pacific Northwest can be considered one electricity market, with demand for electricity driven by a growing population. Historically, electricity from hydroelectric dams has been sold to consumers in the Pacific Northwest at prices less than those from other generating sources. This has resulted in a greater use of electricity for space heating and a concentration of electricity-intensive industry, such as aluminum smelting. While aluminum plants demand a steady amount of electricity over hours and months, the shape of the hourly load profile of the Pacific Northwest electricity system is dominated by space heating, and the Pacific Northwest is a winter-peaking system.

For planning purposes, the Pacific Northwest hydro system is assumed to supply about 12,000 average Megawatts (aMW). This corresponds to hydroelectric generation available in a "critical water year" or under worst historical conditions. The hydro system supplies about 16,000 aMW in an average water year. Hydro generation of 12,000 aMW is about half of the electricity generated in the Pacific Northwest. The remainder is generated primarily from natural gas and coal, with smaller amounts from nuclear and wind (NPCC 2005).

Along with consumptive use of water for irrigation and other minor consumptive-use demands, water in the study basin is used for hydropower generation. From upstream to downstream, Table 7 shows the locations and pool heights of the major dams in the study basin, the hydraulic capacity $\left(10^{6} \mathrm{~m}^{3} \mathrm{y}^{-1}\right)$, and the generation capacity (MW) of the dams.

According to the 1995 USGS county data (summed over the study basin), actual electricity generation amounted to $90,302 \mathrm{GWh}$, or $91 \%$ of the total by hydropower, with an additional $6,942 \mathrm{GW} h \mathrm{~h}$ by nuclear and $1,731 \mathrm{GW} \cdot \mathrm{h}$ by coal.

As of February 4, 2010, the installed wind capacity in Washington State is $1848.88 \mathrm{MW}$ (DOE 2010a). In the Middle Columbia, installed wind farms are of 180.2 and $39.6 \mathrm{MW}$, and 230 MW is slated to come online. As of February 4, 2010, installed wind capacity in Oregon is 1758.14 MW (DOE 2010a). In John Day, wind farms of 24.6, 24, 83.16, and 25.2 MW, respectively, are installed, totaling 156.96 MW. As of December 31, 2009, the U.S. had 34,863 MW of total installed wind capacity (DOE 2010b). 
Table 7. Locations and Characteristics of Dams Located on the Columbia River Within the Study Region

\begin{tabular}{|c|c|c|c|c|c|c|c|c|}
\hline Dam & Watershed & $\begin{array}{l}\text { Columbia } \\
\text { River } \\
(\mathrm{km})\end{array}$ & $\begin{array}{l}\text { Spillway } \\
(\mathrm{m})\end{array}$ & $\begin{array}{l}\text { Pool } \\
\text { height } \\
\text { (High) }\end{array}$ & $\begin{array}{l}\text { Pool } \\
\text { height } \\
\text { (Low) }\end{array}$ & $\begin{array}{c}\text { Hydraulic } \\
\text { Capacity- } \\
\text { First Pump } \\
\text { House } \\
\left(10^{6} \mathrm{~m}^{3} \mathrm{y}^{-1}\right)\end{array}$ & $\begin{array}{c}\text { Name plate } \\
\text { Capacity- } \\
\text { First Pump } \\
\text { House } \\
\text { (MW) }\end{array}$ & $\begin{array}{l}\text { Second } \\
\text { Pump }\end{array}$ \\
\hline $\begin{array}{l}\text { Grand } \\
\text { Coulee }\end{array}$ & $\begin{array}{c}\text { Upper } \\
\text { Columbia }\end{array}$ & 960 & & 393 & 368 & 250,211 & 6465 & \\
\hline $\begin{array}{l}\text { Chief } \\
\text { Joseph }\end{array}$ & & 877 & & 291 & 283 & 195,701 & 2069 & \\
\hline Wells & & 830 & & 238 & 235 & 196,595 & 774 & \\
\hline $\begin{array}{l}\text { Rocky } \\
\text { Reach }\end{array}$ & & 762 & & 215 & 214 & 196,595 & 1347 & \\
\hline $\begin{array}{l}\text { Rock } \\
\text { Island }\end{array}$ & & 730 & & 187 & 186 & & 212 & 410 \\
\hline Wanapum & & 669 & & 174 & 171 & & 1038 & \\
\hline $\begin{array}{l}\text { Priest } \\
\text { Rapids }\end{array}$ & & 639 & & 148 & 147 & & 956 & \\
\hline $\begin{array}{c}\text { Ice } \\
\text { Harbor } \\
\text { (on Snake } \\
\text { River) }\end{array}$ & Snake & 16 & 180 & 134 & $\begin{array}{l}133- \\
134\end{array}$ & 94,723 & 603 & \\
\hline McNary & $\begin{array}{l}\text { Grande } \\
\text { Ronde; } \\
\text { Yakima }\end{array}$ & 470 & 399 & 109 & $\begin{array}{c}102- \\
104\end{array}$ & 207,318 & 980 & \\
\hline John Day & John Day & 347 & 374 & 82 & 78 & 287,743 & 2160 & \\
\hline
\end{tabular}

According to The Fifth Northwest Electric Power and Conservation Plan (NPCC 2005), whole region electricity generation was composed of $52 \%$ hydro, $21 \%$ natural gas, $20 \%$ coal, $3 \%$ biomass, $1 \%$ wind, $3 \%$ nuclear, and $0 \%$ oil. The Fifth Northwest Electric Power and Conservation Plan (NPCC 2005) also includes the following:

For hydropower most economically and environmentally feasible sites have been developed. The remaining opportunities are numerous but small scale. The fifth plan calls on utilities to acquire renewable energy projects including hydropower upgrades as cost-effective opportunities arise. 
For the whole Pacific Northwest region, the Bonneville Power Administration (BPA) markets roughly half of the electricity used in Oregon, Washington, Idaho, and western Montana ${ }^{8},{ }^{9}$. The BPA is a federal agency based in Portland that sells power from 31 federal dams; the Columbia Generating Station, a non-federal nuclear plant located on the Hanford site in eastern Washington; and other nonfederal hydroelectric and wind energy generation facilities ${ }^{10}$. Moreover, it controls approximately $75 \%$ of the transmission lines in the region.

The BPA is part of the Federal Columbia River Power System (FCRPS), a unique collaboration among three U.S. government agencies - the BPA, the U.S. Army Corps of Engineers, and the Bureau of Reclamation. In the past, the BPA has sold power at the cost of generation with no markup, which is one of the reasons why the Pacific Northwest has enjoyed the cheapest power rates in the country. This source of inexpensive electricity was a major attraction for energy-intensive industries, such as aluminum, food processing, and plutonium production for national defense. In addition, the mining industry was a major beneficiary because inexpensive electricity greatly reduced the costs of extracting various metals. This resulted in other industries, such as aerospace, being attracted to the area because they wanted proximity to a resource (in this case, aluminum) being manufactured in the Northwest. ${ }^{11}$ However, the aluminum processing and aerospace industries are located just outside the Columbia River Basin proper, and only three aluminum plants can be found in the subbasin —a 229 Mton per year plant with an electricity demand of $428 \mathrm{MW}$ in Chelan County in the Upper Columbia area (Washington); a 166 Mton per year plant with an electricity demand of 317 MW in Klickitat in the Middle Columbia (Washington); and an 84 Mton per year plant with an electricity demand of $167 \mathrm{MW}$ in the Deschutes River (Wasco, Oregon). ${ }^{12}$

Wholesale spot market electricity prices at the Middle Columbia pricing point from JanuaryDecember 2003 hovered around \$40/MWh (low \$28; high \$50) (NPCC 2005). Levelized annual average electricity price at the Middle Columbia trading hub for 2005 through 2025 is forecast to be $\$ 36.30$ per MWh (\$2000):

Prices decline between 2005 and 2010 reflecting declining natural gas prices. Prices increase gradually through the remainder of the planning period as slowly increasing natural gas prices are partially offset by improved combined-cycle efficiency and increasingly more costeffective wind power (NPCC 2005, Vol. 2, p. 25).

\subsection{Major Issues-Water, Energy, and Salmon}

Since decisions about water typically are not made within a market structure, rather through administrative or legal frameworks, we have to construct a system that will allow us to understand how decisions made under a market system might vary from current decisions.

\footnotetext{
${ }^{8} \mathrm{http} / / /$ en.wikipedia.org/wiki/Bonneville_Power_Administration.

${ }^{9} \mathrm{http}: / /$ www.bpa.gov/corporate/.

${ }^{10}$ www.bpa.gov/corporate/pubs/Keeping/99kc/kc0799.pdf.

${ }^{11}$ www.fwee.org/c-basin.html.

${ }^{12}$ The aluminum companies Kaiser, Goldendale Northwest, and Columbia Falls have profited the most from the resale of BPA power.
} 
Typically, water is an input in most of its uses, not a final consumption item. Water for final consumption actually is a small component of the overall water budget. Therefore, we can make most of the decisions about water based on the implications of making changes in input levels for levels of output. The three main uses for water in the Columbia Basin are provision of streamflow to support salmon, hydroelectric generation, and irrigation. The outputs of water for electricity can be directly valued using market prices, and we have a good understanding of the productivity effects for changes in water inputs for these processes to make reliable valuations of the impacts of changing the available water for these activities. For salmon, we do not have a good sense of the impact of additional water for streamflow. First, the impact of additional water on the size of a subsequent returning salmon cohort is highly uncertain. Second, because of the importance of the non-market value attached to the existence of the salmon fisheries (for which the value of additional salmon is unclear), the value of an increased cohort size is not well defined. Thus, $(\mathrm{Mg}$ $\mathrm{ha}^{-1}$ ) the value of additional salmon reflects both its market value and whatever implications the fish has for the survival of the fishery. There are methods to define existence value, which are rough compared to the price of crops and electricity. However, there is no clear idea of how more fish today affect the future size or existence of the fishery.

The Columbia River Basin has significant variation in annual total flow, as well as a major variation in flow during the year due to the importance of snowpack as a storage mechanism. Climate change is likely to reduce snowpack substantially, reducing the ability to manage the system. Currently, the system can normally be managed to meet the three main users and a number of other high-value consumptive users, such as residential or manufacturing. It is an open question if this will be the case under foreseeable increases in regional temperatures due to global warming.

\subsubsection{Electricity}

There is more generation capacity on the Columbia River than there is water to power it. Water removed from the system for irrigation purposes or other consumptive uses reduces the ability of the system to generate electricity. Because there is a substantial market for peak load capacity for the California electricity market, the value of the electricity is complex to assess. Limitations are also imposed by the need to maintain streamflow and temperature to support the various salmon fisheries. Therefore, computing the value of water for hydroelectric generation depends on the timing of the reductions.

\subsubsection{Irrigation}

Irrigation needs are negatively correlated with streamflow, being highest in the period of lowest flow. Further, different crops respond differently to reductions in available water. For some crops where the underlying systems require substantial time to reach maturity, there is the potential for a substantial loss of capital in addition to the loss of current period production.

\subsubsection{Salmon}

A major problem with salmon is, despite extensive study, the factors that determine salmon prevalence are not discernable because a major portion of their life cycle takes place in the ocean 
where factors determining survival are not well understood. Further, beyond the issue of salmon numbers and the commercial value of the fishery and associated activities, there are existence values reflected in legislation and regulations mandating certain flows be maintained to preserve the fisheries.

\subsubsection{Decision problem}

The question that we wish to pose is how different the water allocation would be if we could balance the marginal product of water in its different uses. For the purposes of this experiment, we will treat municipal and industrial uses of water as given (or of such high value that they will be met). This allows the focus to remain on the major tradeoffs in the basin-irrigation, hydropower, and the salmon fishery. These tradeoffs occur in a river basin characterized by highly uncertain flows, which can only be forecast imperfectly. Further, the value of maintaining streamflow for salmon is also highly uncertain, both in the short run due a poor understanding of the salmon life cycle in the ocean and in the long term as current river temperatures are already close to the expected maximum sustainable level.

Given the uncertainty about the benefit of returning more (or less) streamflow for salmon, it is not possible to balance the return to salmon use against the shadow price of water for irrigation or hydropower. We can construct two simple experiments to help us understand the extent to which the current system may have deviated from an optimal economic allocation of water. In the first experiment, we hold the current allocation of water to maintain the salmon fishery fixed and analyze the extent (if any) of the imbalance between irrigation and hydropower for three scenarios - an average year, a high-flow year, and a low-flow year. For high- and low-flow years, we use the 90 and 10 percentage points on the historical distribution of flows. In the second experiment, we reallocate all of the water currently reserved for streamflow to irrigation and hydropower in an optimal format and estimate what the increase in the value of these two streams would be under the same three scenarios used in the first experiment. This provides an estimate of the shadow price of the current legal and administrative mechanisms used to protect the salmon fishery.

In an ancillary analysis, we also examine how climate change may affect the streamflow, either annually or by changing the within-year distribution of streamflows. This will allow us to reach a qualitative judgment of the climate's impact on the shadow prices estimated with the other two experiments.

\subsection{The Future-Climate Change, Legal Issues, and Demographic Changes}

\subsubsection{Climate change}

The water balance of the Columbia River will be impacted in many ways by a changing climate. Most directly, a change in precipitation amount or timing would considerably alter the balance of water use for irrigation, energy, and other uses. Indirectly, changes such as an increase in temperature might drive up the electricity demand of the region, putting increased pressure on the hydropower system. An analysis of 11 Global Climate Model (GCM) runs for the 
Intergovernmental Panel on Climate Change (IPCC) Fourth Assessment report by Mote et al. (2005) produced a suite of possible climate futures for the Pacific Northwest. The range of warming is projected to be $2-5^{\circ} \mathrm{C}$ by the end of this century, with the highest increases occurring in summer. Changes in precipitation, ranging from a $2 \%$ decrease to an $18 \%$ increase, are not expected to be distinguishable from natural variability until late in the century. Annual patterns of change will likely result in an increase in winter precipitation and a decline in summer precipitation. Under the simulations, the general pattern of winter rainfall will continue.

In general, the projection is for a Pacific Northwest with hotter, drier summers and warmer, wetter winters. This has substantial implications for water demand, which would likely increase in the hotter summers as additional irrigation is needed to mitigate heat stress on crops and energy demands increase. Since natural water storage in snowpacks will decline with increasing temperature, it also highlights the importance of water storage. These results are consistent with an earlier study by Payne et al. (2004), which found moderate precipitation changes and a climate change response dominated by temperature changes. Winter snow accumulation was reduced, and river flow shifted from summer to winter, causing increased competition for reservoir storage.

The Environmental Policy Integrated Climate (EPIC) model was parameterized with data for three representative farms in the basin and executed with climate changes from the upper, middle, and lower parts of this range for periods centered around 2020, 2040, and 2090. The EPIC model simulates agricultural production and irrigation demand. Each representative farm was simulated with three crops (wheat, corn, and hay) and for a range of irrigation application scenarios (Figures 5 and 6).
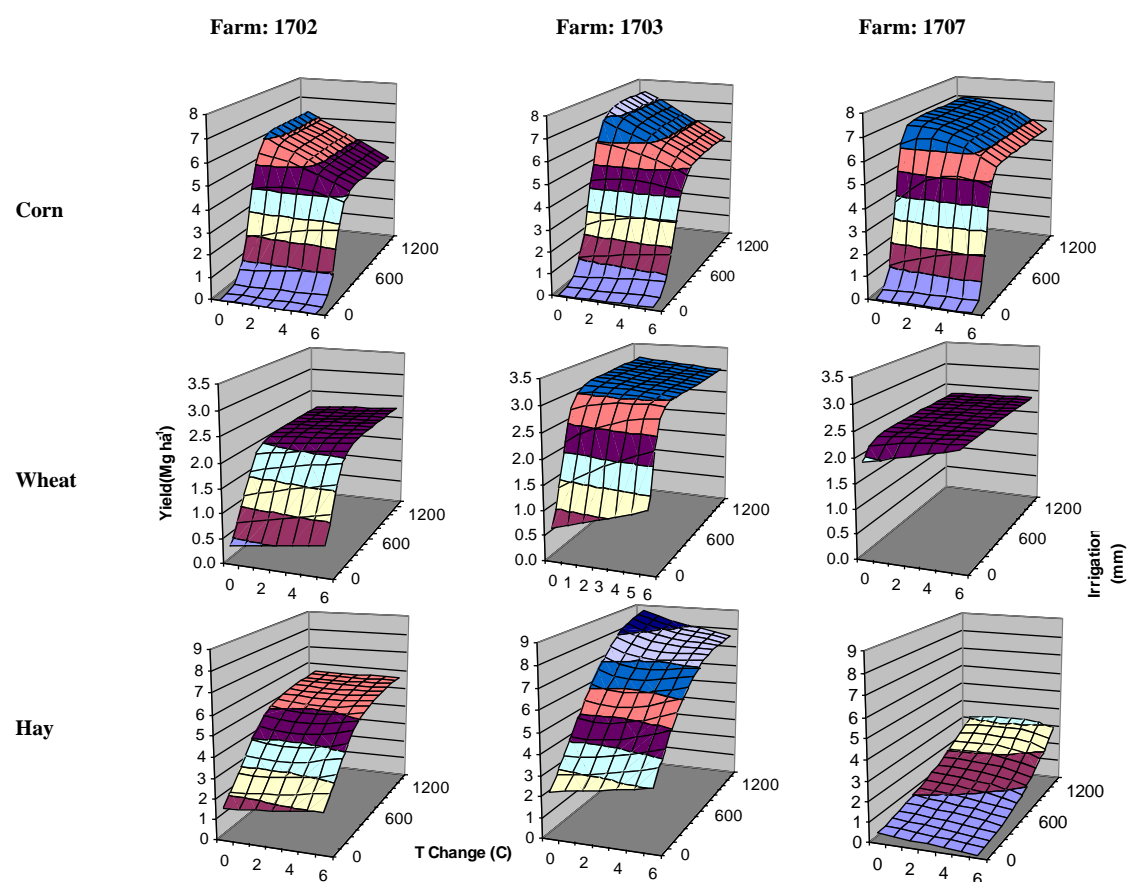

Figure 5. Surface Responses of Crop Yield $\left(\mathrm{Mg} \mathrm{ha}^{-1}\right)$ as Affected by Increases in Global Mean Temperatures and Atmospheric $\mathrm{CO}_{2}$ Concentrations in the Columbia Basin 
The simulations were intended to inform the analysis of the potential range of future irrigation demand and how much the physical water demand of crops will increase. This information was used to inform the development of the prototype model as detailed in Section 4.
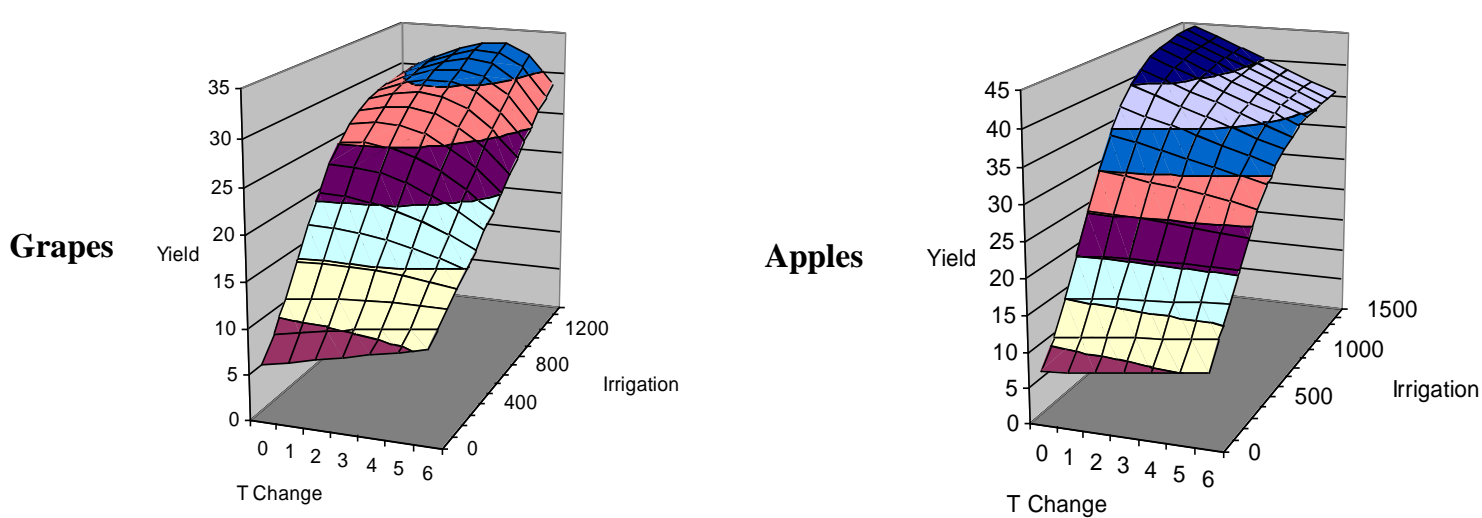

Figure 6. Surface Responses of Grape and Apple Yields $\left(\mathrm{Mg} \mathrm{ha}^{-1}\right)$ as Affected by Increases in Global Mean Temperatures and Atmospheric $\mathrm{CO}_{2}$ Concentrations in the Columbia Basin

\subsubsection{Demographics}

Population projections for the period 2010-2030 show a 25\% increase over a current 6.7 million estimated population for Washington ${ }^{13}$ and a $19 \%$ increase over a current estimated population of 3.8 million for Oregon ${ }^{14}$. If we project and apportion these increases, it would mean the study basin, by 2030, would have a quarter of a million more people than it does today.

\subsubsection{Water rights}

In the Columbia River Basin, water is allocated based on an established system of water rights. New water rights can only be granted through a legal process informed by consideration of all water demands in the basin, particularly concern for endangered salmon species. A recent report from the National Academy of Sciences (2004) evaluated the river flows with regard to ensuring salmon survival and provided recommendations on the amount and timing of water withdrawals from the system. The structure of water rights may also form a central consideration of the response of agriculture to climate change. In a study of agriculture in the Yakima River, Scott et al. (2004) concluded that greater institutional flexibility would be needed to make effective use of climate forecasts and respond to projected changes in climate.

\footnotetext{
${ }^{13}$ http://www.ofm.wa.gov/pop/stfc/default.asp.

${ }^{14}$ http://www.oregon.gov/DAS/OEA/demographic.shtml\#Short_Term_State_Forecast.
} 


\subsection{Description of Prototype Model}

\subsection{Description of the Water Prototype Model}

\subsubsection{Objective}

The objective is to build a modeling capability that can be applied to understand how water is allocated within a river basin and develop a system for modeling present and future water allocations among agriculture, energy production, other human requirements, and ecological needs.

\subsubsection{Modeling platform}

The Water Prototype Model (WPM) was built in STELLA ${ }^{\circledR 15}$, a computer modeling package with an easy, intuitive interface that allows users to construct dynamic models that realistically simulate and integrate many processes (biological, hydrological, economics, sociological), as described by Costanza and Voinov (2001):

STELLA includes a procedural programming language that is useful to view and analyze the equations that are created as a result of manipulating the icons. The essential features of the system are defined in terms of stocks (state variables), flows (in and out of the state variables), auxiliary variables (other algebraic or graphical relationships or fixed parameters), and information flows. Mathematically, the system is geared towards formulating models as systems of ordinary differential equations and solving them numerically as difference equations. The user places the icons for each of the stocks in the modeling area and then connects them by flows of material or informational relationships. Next the user defines the functional relationships that correspond to these flows. These relationships can be mathematical, logical, graphical, or numerical.

\subsubsection{Model description}

A general diagram of the model is shown in Figure 7, and a display of the results produced by the model, including a picture of the modeled basins, is shown in Figure 8. As previously described, the study basin occupies $150,404 \mathrm{~km}^{2}$ and is part of the larger Columbia River Basin in the U.S. Pacific Northwest region. About $60 \%$ of the study basin rests in the state of Washington, and the rest is in Oregon. The Columbia River runs through the basin for $874 \mathrm{~km}$ starting at the international border with Canada $\left(49^{\circ} 00^{\prime}, 117^{\circ} 38^{\prime}\right)$ and ending (for the purpose of the simulation) at The Dalles Dam $\left(45^{\circ} 37^{\prime}, 121^{\circ} 08^{\prime}\right)$. Water enters the basin through precipitation and from streamflows originating from the Columbia River at the international border, the Spokane River, and the Snake River. Water leaves the basin through evapotranspiration, consumptive uses (irrigation, livestock, domestic, commercial, mining, industrial, and off-stream power generation), and streamflow through The Dalles Dam. Water also enters the Columbia River via runoff from land (both surface and subsurface). The model runs on a monthly time scale

\footnotetext{
${ }^{15} \mathrm{http} / / /$ www.iseesystems.com/softwares/Education/StellaSoftware.aspx.
} 
to account for the impact of seasonal variations of climate (interannual variability or ENSO and climate change), streamflows, and water uses. A salmon policy feature was included to capture the influence of flow augmentation on smolts migration to the ocean and the consequent reduction on hydropower production.

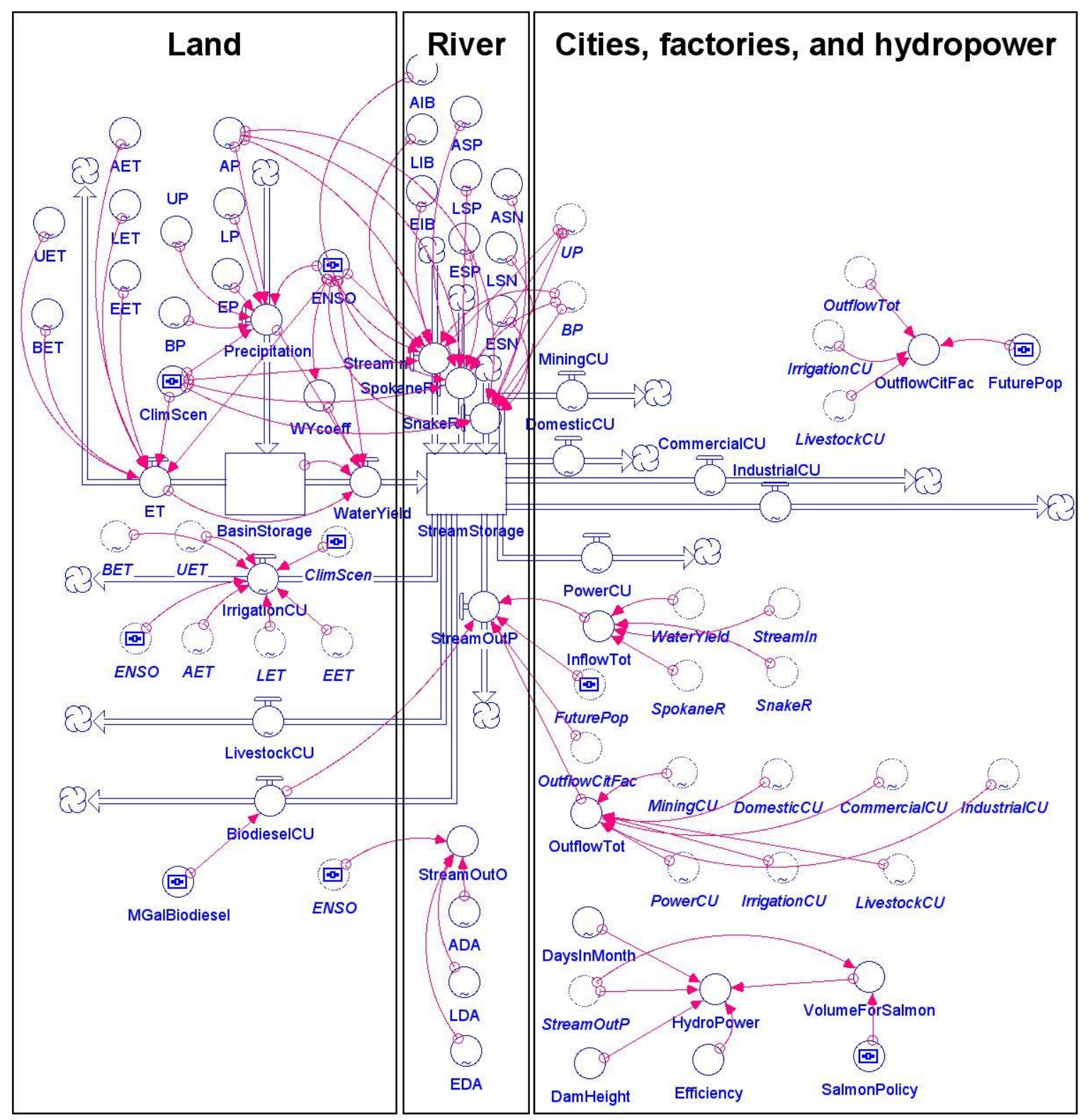

Figure 7. Model Diagram Showing the Larger Compartments (i.e., land, river, etc.) and the Stocks and Flow Occurring Throughout 


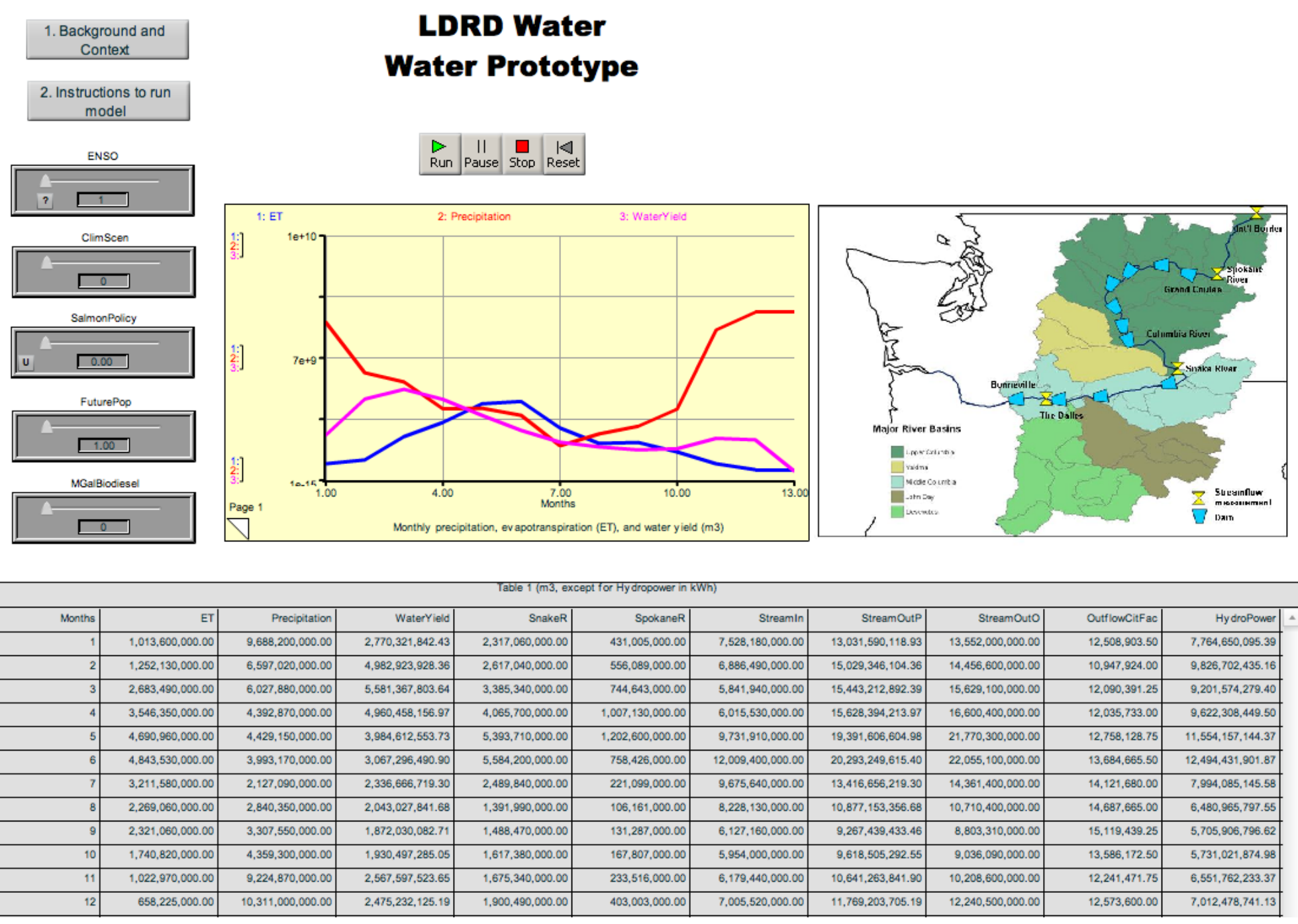

Figure 8. Screenshot of the Water Prototype Model Interface 


\subsubsection{Fundamental equations}

The fundamental equations used to build the model concern the storage and transfer of water within the study basin.

$$
\frac{\partial B}{\partial t}=P-E T-W Y
$$

where $\partial \mathrm{B} / \partial \mathrm{t}=$ change in basin storage $\left(\mathrm{m}^{3}\right), P=$ precipitation $\left(\mathrm{m}^{3}\right), E T=$ evapotranspiration $\left(\mathrm{m}^{3}\right)$, and $W Y=$ water yield $\left(\mathrm{m}^{3}\right)$.

$$
W Y=f\left(B_{t}+P-E T\right)
$$

where $f=$ fraction (dimensionless) and $B_{t}=$ basin storage at time $\mathrm{t}\left(\mathrm{m}^{3}\right)$. The value of $f$ was derived from the $W Y$ output.

Due to lack of a clear difference between climate change scenarios, water yield was made a function of ENSO scenarios but not of climate change.

The water content of the basin $\left(\mathrm{B}_{\mathrm{i}}, \mathrm{m}^{3}\right)$ was initialized at $50 \%$ of the available soil water capacity to a depth of $2 \mathrm{~m}$. Data for this calculation were derived from the soil database residing in the hydrological HUMUS model (Thomson et al. 2003 and 2005b).

$$
\frac{\partial S}{\partial t}=\sum S_{i}-S_{o}-\sum C U
$$

where $\partial \mathrm{S} / \partial \mathrm{t}=$ change in water volume held by dams $\left(\mathrm{m}^{3}\right), \Sigma \mathrm{S}_{\mathrm{i}}=$ total incoming streamflow from tributaries outside basin $\left(\mathrm{m}^{3}\right), S_{o}=$ streamflow at basin outlet $\left(\mathrm{m}^{3}\right)$, and $\Sigma \mathrm{CU}=$ total consumptive use by different sectors $\left(\mathrm{m}^{3}\right)$. Data for the monthly values of $C U$ were derived from USGS databases for the year 1995, the last reporting period with water use data reported at the 8digit HUC available at the writing of this report.

The change in water storage $\partial \mathrm{S} / \partial \mathrm{t}$ was assumed to be 0 . Thus, $S_{o}$ was calculated as:

$$
S_{o}=\sum S_{i}-\sum C U
$$

In case $\partial \mathrm{S} / \partial \mathrm{t} \neq 0, S_{o}$ can be recalculated based on extra water additions or withdrawals.

The monthly variability of $S_{o}$ was modeled by imposing ENSO and climate change scenarios to baseline conditions existing for $P, E T$, and streamflows. Two ENSO scenarios are represented in the WPM model, La Niña and El Niño (Thomson et al. 2003). The two scenarios of climate change were taken from results from the HUMUS model (Thomson et al. 2005b), Australian Bureau of Meteorological Research Centre (BMRC), and University of Illinois, Urbana Champaign (UIUC) for a $1{ }^{\circ} \mathrm{C}$ increase in global mean temperature (GMT). 
Consumptive use due to irrigation was made a function of ENSO and climate change scenarios. A scenario of biodiesel production was also included to capture the influence of bioenergy production in the Pacific Northwest on water demand. The scenario is based on biodiesel production from irrigated canola. Data used to calculate the water demand include: canola yield, water use efficiency, oil concentration in canola seed, biodiesel production from canola oil, and irrigation requirements.

Calculation of hydropower $(H P, \mathrm{~W})$ was calculated as:

$$
H P=h \times S \times E \times g \times \delta
$$

where $h=$ dam height (m), $S=$ streamflow $\left(\mathrm{m}^{3} \mathrm{~s}^{-1}\right), E=$ efficiency factor (dimensionless), $g=$ acceleration of gravity $\left(\mathrm{m} \mathrm{s}^{-2}\right)$, and $\delta=$ density of water $\left(\mathrm{kg} \mathrm{m}^{-3}\right)$.

To simulate the effect of flow augmentation on hydropower production, a simple procedure was added to the model. Flow augmentation is a policy option available to facilitate the migration of salmon smolts from upstream to the ocean. At the moment, the model does not consider the effect of other features, such as barging. Future updates of the WPM will include a simplified version of the Smolts Migration Model developed by the BPA. ${ }^{16}$ This model calculates the travel time and survival of smolts batches released from hatcheries as affected by high or low flow, mortality, barging, turbines, and flow augmentation.

\subsubsection{Data sources}

Precipitation, evapotranspiration, and water yield data were extracted from databases containing results obtained with the HUMUS model runs for the conterminous U.S. under baseline, ENSO, and climate change scenarios (Thomson et al. 2003 and 2005b). Consumptiveuse data were derived from the USGS water use database ${ }^{17}$ for 1995 available at the 8-digit HUC level and aggregated across the basin.

Hydropower data — dam height $(\mathrm{m})$, nameplate capacity $(\mathrm{kW})$, and hydraulic capacity $\left(\mathrm{m}^{3} \mathrm{~s}\right.$ ${ }^{1}$ ) — were obtained from various sources, including the U.S. Department of Interior and the U.S. Army Corps of Engineers. A weighted average approach based on active dam capacity $\left(\mathrm{m}^{3}\right)$ was used to calculate the height of a composite dam made of 10 dams: Grand Coulee, Chief Joseph, Wells, Rocky Reach, Rock Island, Wanapum, Priest Rapids, McNary, John Day, and The Dalles. The surface areas of the lakes above each dam were calculated using width and length values estimated with Google Earth.

\subsubsection{How to run the model}

The WPM can be run from three sources: 1) directly from STELLA software, 2) with the isee Player $^{\circledR}$, or 3) the web version of WPM constructed with NetSim ${ }^{\circledR}$ software posted at http://forio.com/broadcast/netsim/netsims/rcizaurra/waterprototype/index.html.

\footnotetext{
${ }^{16} \mathrm{http} / / /$ www.bpa.gov/Corporate/KR/ed/step/smolts/SmoltsM.shtml.

${ }^{17} \mathrm{http}: / /$ water.usgs.gov/watuse/.
} 
When running any of these three versions, the user is presented a screen with a series of buttons, graphs, and tables (see Figure 8). Two of the buttons provide the user with background and instructions on how to run the model. Currently, there are five types of scenarios that can be manipulated alone or in combination using the Sliding Input Devices: 1) ENSO, 2) climate change (ClimScen), 3) salmon policy, 4) future population (FuturePop), and 5) biodiesel production (MGalBiodiesel).

The ENSO scenario allows for three choices: 1) all years, 2) La Niña years, and 3) El Niño years.

The climate change scenarios are: 0) baseline, 1) predictions from BMRC GCM for $1^{\circ} \mathrm{C}$ increase in GMT, and 2) predictions from UIUC GCM for 1-degree increase in GMT.

The salmon policy slide rule allows the user to set a fraction of streamflow away from hydropower production and redirect it to help smolts travel to the ocean during the spring. The biodiesel slider input device allows the user to select different levels of biodiesel production, from zero to 20 million gallons per year. Based on this information, the model calculates the extra water demand during the growing season.

The future population (FuturePop) input device allows the user to select a population increase $(1.0-1.3)$ that will affect the consumptive uses by domestic, commercial, industrial, mining, outof-stream power, and livestock sectors.

Finally, the biodiesel policy input device (MGalBiodiesel) allows the user to select a level of annual production of biodiesel (0-20 million gallons of biodiesel per year) from irrigated canola and its impact on water demand.

\subsubsection{Examples and discussion of selected model outputs}

One of the fundamental premises for this capability development activity was to build a model prototype capable of describing the supply and demand of water at the basin scale yet to be simple and scalable enough for its inclusion into an integrated model, such as MiniCAM. Figure 9 compares predicted and observed streamflow at The Dalles under average weather conditions, as well as those of La Niña and El Niño. In general, the predicted monthly flows agree quite well with the observed values. This was achieved through the integration of observations with modeled data and predictions of hydrological variables. The model also responded to scenarios of climate change (data not shown). Although due to the climate change scenarios selected, the changes in streamflow were not dramatically different from those of the baseline conditions.

One of the important dynamics from the perspective of IA modeling is the consequence of changes in the prototype variables for hydropower production. Under La Niña conditions, more hydropower is available during all months of the year, with a substantially higher availability in the spring and summer months. Conversely, under El Niño conditions, hydropower will be less available, with a total decline of $15 \%$ from normal weather conditions over the year. By contrast, imposing a policy where water remains in the river for salmon migration has a smaller, but negative, impact on the total annual supply of hydropower. Modeled hydropower generation was $23 \%$ greater than the 81 TWh reported in the 1995 USGS database (Figure 10). 


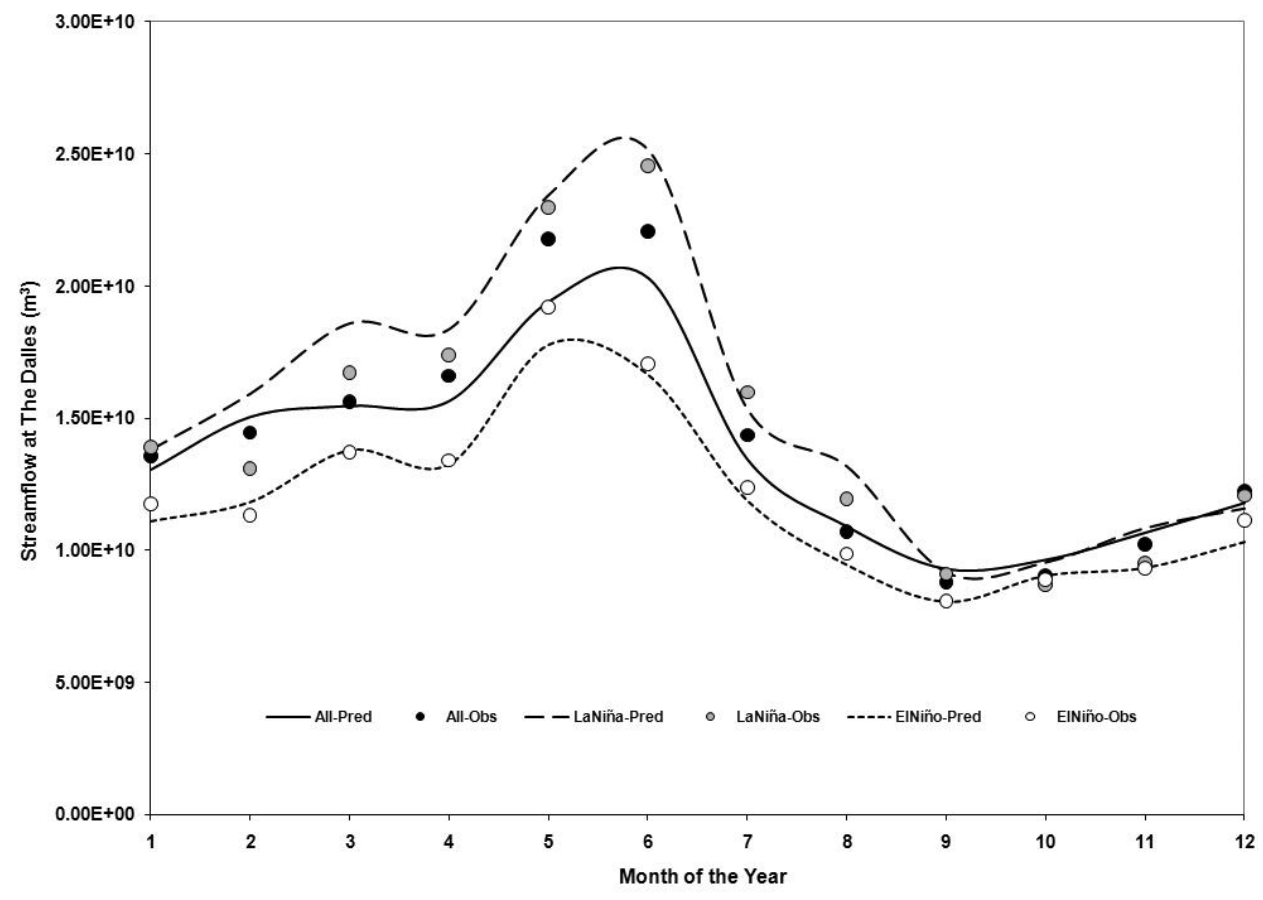

Figure 9. Predicted and Observed Streamflows (m3) at The Dalles as Affected by ENSO Scenarios

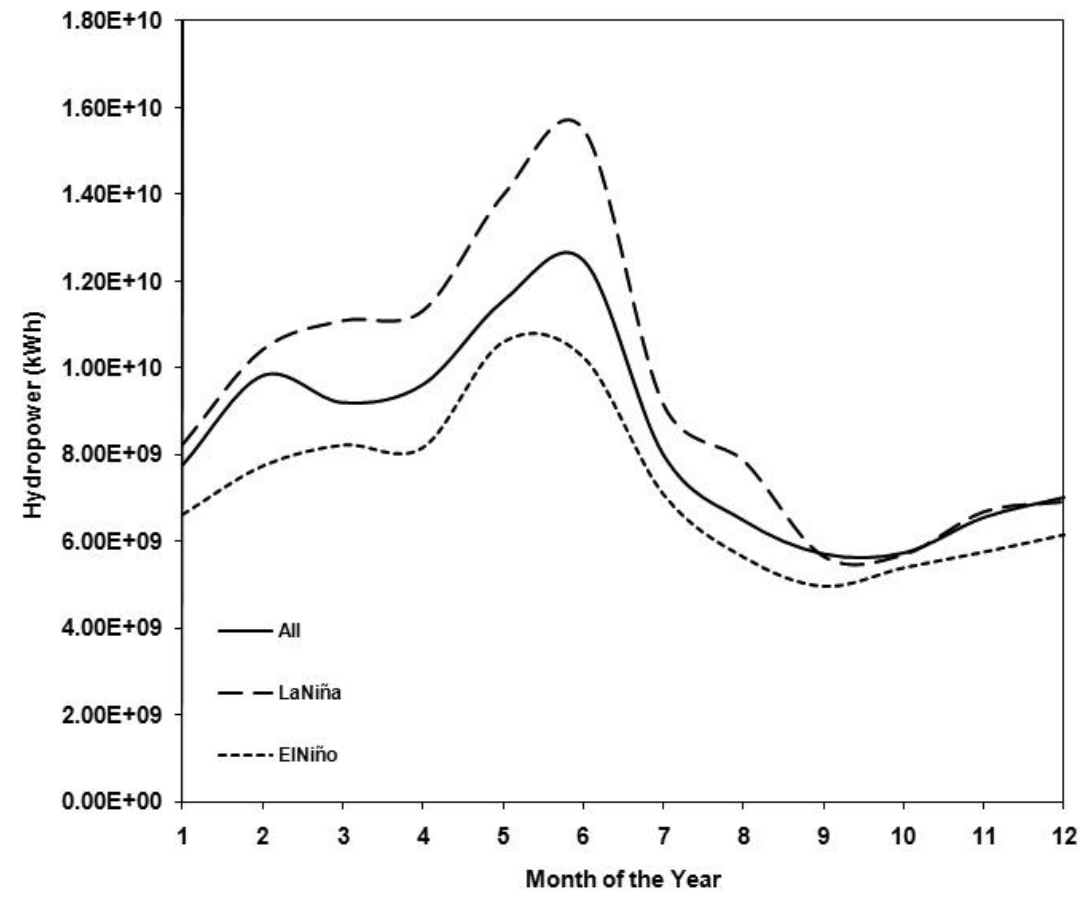

Figure 10. Monthly Hydropower (kWh) as Affected by ENSO Scenarios 
This prototype can be applied to gain understanding of the quantitative dynamics of water supply and the consequences for different economic sectors, including withdrawals for industry, energy use, and energy production in the region. In particular, it can be used in the design of an IA water module to provide insight into the factors affecting allocation of available water among the competing demands. Once this allocation is understood, economic drivers and controls on water can be incorporated into the prototype. Then, this will inform the process of applying prices to water in this and other regions for IA modeling.

\subsubsection{Summary and future steps}

A WPM to describe water allocation within a basin among multiple uses (agriculture, energy production, other human requirements, and ecological needs) has been presented and discussed. The modeling capability is considered the initial step to incorporate water into IA models. The WPM allows for the analysis of the interactions among water uses in a manner that could be directly assimilated into IA frameworks. However, to be practical for use in integrated assessments, it would have to be expanded or scaled up, first nationally, then to the global level. As demonstrated with the WPM, a spatial scale of a 2-digit basin is considered appropriate to represent water supply and demand issues for IA. In the case of the conterminous U.S., this would translate into scaling the WPM to represent 18 major river basins. All of the data and model results are available to accomplish this model expansion.

However, specific model enhancements would be required to bring realism to the dynamics of water in different basins. One example is groundwater extractions. Currently, the WPM does not contain a way to account for water extractions from groundwater resources, yet the underlying data exist (USGS databases) for representing this process. Another example is water demand for cellulosic ethanol production, especially involving bioenergy crops such as switchgrass (Panicum virgatum L.) and miscanthus (Miscanthus x giganteus), as well as water demand associated with biorefineries.

By adding a one-reservoir submodel to describe the spring migration of smolts to the ocean and associated policies, the salmon policy currently available in the WPM will be updated in the near future. The essential features of this submodel are presented in Figure 11. The one-reservoir submodel is a simplification of the BPA's more complex model, which includes several reservoirs along the Snake and Columbia rivers.

As presented, the WPM offers all of the necessary ingredients to conduct economic analyses of various policy options for water allocation. Even the difficult question of the valuation of water allocation for salmon survival can be indirectly estimated through its impact on hydropower production or water withdrawals for irrigation. Further work is needed in this area. 


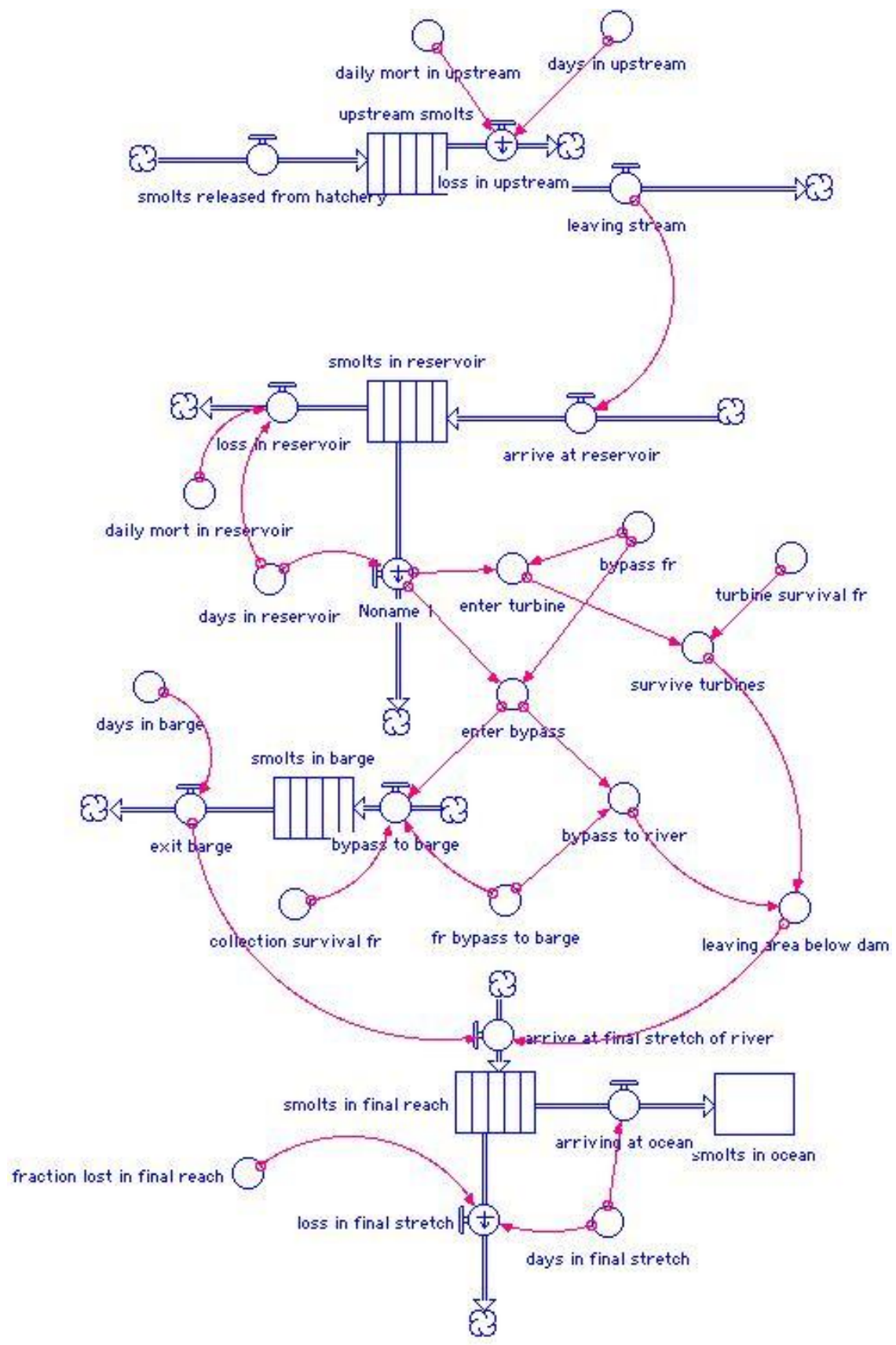

Figure 11. Simplified Version of the Bonneville Power Administration Model to Describe Smolts Migration to the Ocean 


\subsection{References}

Costanza R and A Voinov. 2001. "Modeling ecological and economic systems with STELLA: Part III.” Ecological Modelling 143(1-2):1-7.

DOE - U.S. Department of Energy. 2010a. Installed Wind Capacity by State. Accessed November 17, 2010 at http://www.windpoweringamerica.gov/wind_installed_capacity.asp (last updated February 4, 2010).

DOE - U.S. Department of Energy. 2010b. Current Installed Wind Capacity Map. Accessed November 17, 2010 at

http://www.windpoweringamerica.gov/images/windmaps/installed_capacity_current.jpg (last updated December 31, 2009).

Gedalof Z, DL Peterson, and NJ Mantua. 2004. "Columbia River Flow and Drought Since 1750." JAWRA Journal of the American Water Resources Association 40(6):1575-1592.

Izaurralde RC, NJ Rosenberg, RA Brown Jr, and AM Thomson. 2003. "Integrated Assessment of Hadley Centre (HadCM2) Climate-Change Impacts on Agricultural Productivity and Irrigation Water Supply in the Conterminous United States. Part II. Regional Agricultural Production in 2030 and 2095." Agricultural and Forest Meteorology 117(1-2):97-122.

Matheussen B, RL Kirschbaum, IA Goodman, GM O’Donnell, and DP Lettenmaier. 2000. "Effects of land cover change on streamflow in the interior Columbia River Basin (USA and Canada)." Hydrological Processes 14(5):867-885.

Mote PM, EP Salathé, and C Peacock. 2005. Scenarios of Future Climate for the Pacific Northwest. A report prepared for King County Department of Natural Resources by the Climate Impacts Group, Center for Science in the Earth System, Joint Institute for the Study of the Atmosphere and Ocean, 13 pp, University of Washington, Seattle.

NPCC - Northwest Power and Conservation Council. 2005. The Fifth Northwest Electric Power and Conservation Plan. Council Document 2005-07, Portland, Oregon. Accessed November 12, 2010 at http://www.nwcouncil.org/energy/powerplan/5/Default.htm.

NRC - National Research Council. 2004. Managing the Columbia River: Instream Flows, Water Withdrawals, and Salmon Survival. National Academies Press, Washington, D.C.

Payne JT, AW Wood, AF Hamlet, RN Palmer, and DP Lettenmaier. 2004. "Mitigating the Effects of Climate Change on the Water Resources of the Columbia River Basin." Climatic Change 62(1-3):233-256.

Rosenberg NJ, RA Brown, RC Izaurralde, and AM Thomson. 2003. "Integrated Assessment of Hadley Centre (HadCM2) Climate Change Projections on Agricultural Productivity and Irrigation Water Supply in the Conterminous United States. I. Climate change scenarios and impacts on irrigation water supply simulated with the HUMUS model." Agricultural and Forest Meteorology 117(1):73-96. 
Sands RD and JA Edmonds. 2005. "Economic analysis of field crops and land use with climate change." Climatic Change 69(1):127-150.

Sands, R.D., and M. Leimbach. 2003. "Modeling Agriculture and Land Use in an Integrated Assessment Framework," Climatic Change 56 (1): 185-210.

Scott MJ, LW Vail, J Jaksch, CO Stöckle, and A Kemanian. 2004. "Water Exchanges: Tools to Beat El Niño Climate Variability in Irrigated Agriculture." JAWRA Journal of the American Water Resources Association 40(1):15-31.

Thomson AM, RA Brown Jr, NJ Rosenberg, RC Izaurralde, D Legler, and R Srinivasan. 2003. "Simulated Impacts of El Niño/Southern Oscillation on United States Water Resources." Journal of the American Water Resources Association 39(1):137-148.

Thomson AM, RA Brown, NJ Rosenberg, RC Izaurralde, and V Benson. 2005a. "Climate Change Impacts for the Conterminous USA: An Integrated Assessment Part 3: Dryland Production of Grain and Forage Crops." Climatic Change 69(1):43-65.

Thomson AM, RA Brown, NJ Rosenberg, R Srinivasan, and RC Izaurralde. 2005b. "Climate Change Impacts for the Conterminous USA: An Integrated Assessment Part 4: Water Resources." Climatic Change 69(1):67-88.

Thomson AM, NJ Rosenberg, RC Izaurralde, and RA Brown. 2005c. "Climate Change Impacts for the Conterminous USA: An Integrated Assessment Part 6: Distribution and Productivity of Unmanaged Ecosystems." Climatic Change 69(1): 89-105. 


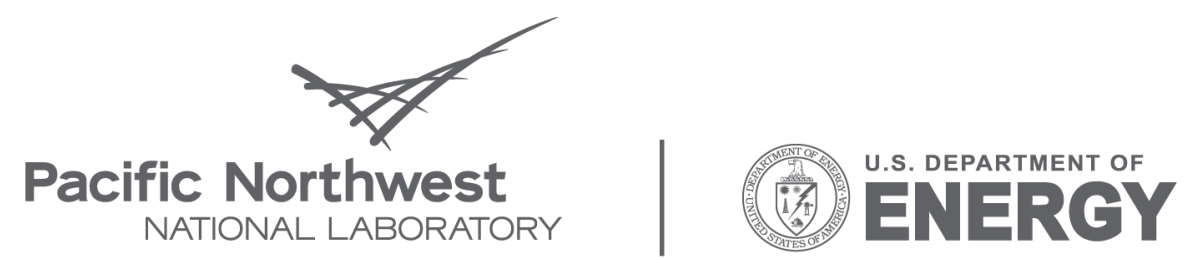

Proudly Operated by Battelle Since 1965

902 Battelle Boulevard

P.O. Box 999

Richland, WA 99352

1-888-375-PNNL (7665)

www.pnl.gov 